\title{
Species richness and functional attributes of fish assemblages across a large-scale salinity gradient in shallow coastal areas
}

\author{
Birgit Koehler ${ }^{1}$, Mårten Erlandsson ${ }^{1}$, Martin Karlsson ${ }^{2}$, Lena Bergström ${ }^{1}$
}

$5{ }^{1}$ Department of Aquatic Resources, Institute of Coastal Research, Swedish University of Agricultural Sciences, Skolgatan 6, 74243 Öregrund, Sweden

${ }^{2}$ Department for Marine Management, The Swedish Agency for Marine and Water Management, Gullbergs Strandgata 15, 41104 Gothenburg, Sweden

Correspondence to: Birgit Koehler (birgit.koehler@slu.se) or Lena Bergström (lena.bergstrom@slu.se)

10 Abstract. Coastal ecosystems are biologically productive and their diversity underlies various ecosystem services to humans. However, large-scale species richness (SR) and its regulating factors remain uncertain for many organism groups, owing not least to the fact that observed SR ( $\mathrm{SR}_{\mathrm{obs}}$ ) is strongly dependent on sample size and inventory completeness (IC). We estimated changes in SR across a natural geographical gradient using statistical rarefaction and extrapolation methods, based on a large fish species incidence dataset compiled from Swedish fish survey databases. The data covered nearly five decades (1975-

15 2020), a 1,300 km north-south distance and a 10-fold salinity gradient along sub-basins of the Baltic Sea plus Skagerrak. Focusing on shallow coastal and offshore areas ( $<30 \mathrm{~m}$ depth), we calculated standardized SR ( $\left.\mathrm{SR}_{\text {std }}\right)$ and estimated $\mathrm{SR}\left(\mathrm{SR}_{\mathrm{est}}\right)$, and related these to sub-basin annual mean salinity and water temperature. IC was high, $98.5 \%-99.9 \%$, in the 10 sub-basins with sufficient data for analysis. The recorded fish species were of $75 \%$ marine and $25 \%$ freshwater origin. Total fish $\mathrm{SR}_{\mathrm{obs}}$

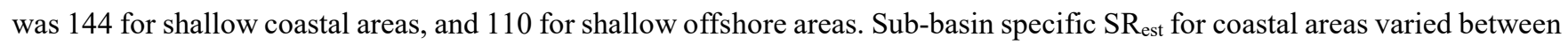

$2035 \pm 7$ (SE) and $109 \pm 6$ fish species, and was ca. three times higher in the most saline (salinity 29-32) compared to the least saline sub-basins (salinity 2.7). Completing information on functional attributes showed that differences along the salinity gradient reflected an increased share of coastal resident fish species in lower salinities, and a higher share of migratory fish at higher salinities. The proportion of benthic and demersal fish species was also lower in the least saline sub-basins, and increased with increasing salinity. If climate change lowers the salinity regime of the Baltic Sea in the future this may hence influence the SR and community composition of fish. 
https://doi.org/10.5194/bg-2021-302

Preprint. Discussion started: 2 December 2021

(c) Author(s) 2021. CC BY 4.0 License.

(c) (i)

\section{Introduction}

Biodiversity is essential for ecosystem processes, and ultimately for the humans depending on these (IPBES, 2019). Coastal ecosystems are often biologically diverse and highly productive, providing valuable ecosystem services to humans, such as food, water purification and protection against floods (Griffiths et al., 2017; Kraufvelin et al., 2018; Pan et al., 2013). However, threats to coastal biodiversity from e.g. overfishing, habitat loss, pollution, eutrophication and climate change are many and profound (Duncan et al., 2015; Griffiths et al., 2017; Pan et al., 2013). At the same time, actually occurring coastal species numbers often remain uncertain (Appeltans et al., 2012). This makes improved understanding of their biodiversity especially important to support conservation and management measures (Pan et al., 2013; Rooney \& McCann, 2012).

Taxonomic inventories, or species censuses, are required e.g. for the analysis of biodiversity patterns, delineation of species ranges, and prioritization of conservation efforts (Mora et al., 2008). Species richness (SR), i.e. the number of species in an ecosystem, is a classical indicator of biodiversity, also referred to as "alpha diversity" (Gotelli \& Colwell, 2001; Hill, 1973). However, since achieving complete species inventories is often impracticable with realistic sample efforts, most censuses remain incomplete and many rare species remain unknown. Consequently, it is important to consider the effect of sample size and inventory completeness (IC) on observed SR ( $\mathrm{SR}_{\mathrm{obs}}$ ) to avoid biased or misleading comparisons or interpretations (Chao \& Chiu, 2016; Chao et al., 2020; Colwell \& Coddington, 1994; Mora et al., 2008).

SR is connected to several ecosystem processes, such as productivity (Duffy et al., 2017), and the efficiency of resource use and nutrient cycling. SR may also facilitate the simultaneous provision of several ecosystem processes, i.e. an ecosystem's multifunctionality (Byrnes et al., 2014). However, since species do not contribute equally to ecosystem functioning, the diversity of species functional attributes adds another important dimension to ecosystem understanding (Duncan et al., 2015;

45 Reiss et al., 2009). Functional diversity can enhance long-term stability, through functional redundancy and complementarity, and can help to buffer ecosystems against disturbances (O'Gorman et al., 2011).

Salinity is a key variable influencing SR in coastal areas, as natural differences in salinity among locations function as a threshold or "ecological barrier" for the distribution of freshwater and marine species (Olenin \& Leppäkoski, 1999; Vuorinen et al., 2015). At the same time, an intensified water cycle caused by global warming is currently changing the salinity regimes

50 of marine and coastal ecosystems (Durack et al., 2012; Liblik \& Lips, 2019; Meier et al., 2021). It is important to understand how salinity influences species' distributions in aquatic ecosystems to be able to better predict how potential changes may affect ecosystem functioning.

The Baltic Sea, one of the world's largest brackish water bodies, exhibits a pronounced, geographically stable salinity gradient that is maintained by sporadic inflows of saline water from the North Sea through the Danish Straits and by freshwater input 55 from large rivers, especially in the north. Hence, the Baltic Sea gradient can serve as model on the influence of salinity on 
https://doi.org/10.5194/bg-2021-302

Preprint. Discussion started: 2 December 2021

(c) Author(s) 2021. CC BY 4.0 License.

\section{(c) (i)}

species distributions (Johannesson \& Andre, 2006; Ojaveer et al., 2010), that has been studied for various organism groups. $\mathrm{SR}_{\mathrm{obs}}$ was often higher at the more saline conditions, e.g. for benthic bacteria, benthic macroalgae and benthic meio- and macrofauna (Broman et al., 2019; Klier et al., 2018; Middelboe et al., 1997). In other studies, SR $_{\text {obs }}$ was highest at highest salinity, lowest at intermediate salinity and intermediate at lowest salinity, e.g. for phytoplankton and benthic macrofauna

60 (Bonsdorff, 2006; Olli et al., 2019; Zettler et al., 2014), or there was no clear trend between $\mathrm{SR}_{\text {obs }}$ and salinity, e.g. for bacterio, pico- and mesoplankton (Herlemann et al., 2016; Hu et al., 2016).

The species composition of fish in the Baltic Sea is regulated by salinity as well (Olsson et al., 2012; Pekcan-Hekim et al., 2016), with fish $\mathrm{SR}_{\mathrm{obs}}$ generally being higher at higher compared to lower salinities (HELCOM, 2020; Hiddink \& Coleby, 2012; Lappalainen et al., 2000; MacKenzie et al., 2007; Ojaveer et al., 2010; Pecuchet et al., 2016; Thorman, 1986). Various studies have also reported changes in fish $\mathrm{SR}_{\text {obs }}$ or species composition over time (e.g. Ammar et al., 2021; Törnroos et al., 2019). However, despite concerns that fish SR may decline in the future due to decreasing upper layer salinity (e.g. MacKenzie et al., 2007; Pecuchet et al., 2016; Vuorinen et al., 2015), information on how the complete coastal fish assemblage varies spatially in relation to the Baltic Sea salinity gradient, including potential differences across functional groups, is lacking. Hence, there is a need to complement already existing information on the influence of salinity on various Baltic Sea organism groups with more complete information in relation to fish diversity, taxonomically and functionally. This kind of understanding for multiple trophic levels is needed to better understand and predict how changing salinity, in the Baltic Sea and in coastal areas in general (Durack et al., 2012; Liblik \& Lips, 2019), may affect ecosystem structure and functioning (MacKenzie et al., 2007). For example, if different species groups are differently affected, this may also change biotic interactions such as benthicpelagic coupling, with effects on exchanges of energy, mass or nutrients between benthic and pelagic habitats (Griffiths et al.,

75 2017). Moreover, understanding species richness at a broader, sub-regional scale is important to support analyses of potential species richness and species compositions at more local scales within each sub-basin.

To this aim, we compiled a large dataset on fish species observations in shallow ( $<30 \mathrm{~m}$ depth) Swedish coastal and offshore areas, based on multiple existing sources of Swedish mapping and monitoring combined over the years 1975-2020. The extensive dataset covered fish species incidence information from 1,848 unique observations/fishing occasions, during which 80 in total 24,415 species incidences were recorded. Geographically, the data covered 12 hydrographically distinct sub-basins, and a ca. ten-fold salinity gradient from close to freshwater conditions in the inner Baltic Sea to close to fully marine conditions at the Swedish west coast. Since $\mathrm{SR}_{\mathrm{obs}}$ is strongly dependent on sample size, which differed between sub-basins, we used statistical rarefaction-extrapolation methods to estimate IC and standardized SR per sub-basin. Further, we categorized each fish species according to origin (marine vs. freshwater) as well as three functional attributes based on coastal habitat preference, 85 vertical preference and feeding habitat, and investigated the influence of salinity (and, for comparison, temperature) on fish SR in total and within the functional attributes. We discuss the results in the context of the regulating influence of salinity on 
https://doi.org/10.5194/bg-2021-302

Preprint. Discussion started: 2 December 2021

(c) Author(s) 2021. CC BY 4.0 License.

(c) (i)

Discussions

fish SR and community composition in coastal ecosystems, and potential implications for conservation and ecosystem management.

\section{Methods}

90

\subsection{Study system}

The Baltic Sea, an enclosed, essentially non-tidal brackish marine region with a maximum and mean depth of 460 and $54 \mathrm{~m}$, respectively, and a water residence time of 25-40 years, is, among the world's largest estuaries (area: 415,000 km²; HELCOM, 2018). Its current brackish conditions were formed by gradual narrowing of its opening to the North Sea and have been in place since ca. 3,000 years (Russell, 1985). Due to its geographically variable but locally relatively stable salinity conditions the Baltic Sea has been called a "marine-brackish-limnic continuum" (Bonsdorff, 2006). Its surface salinity changes from $<3$ (psu) in the inner-most areas in the north and north-east to almost fully marine (ca. 29) in the Kattegat in the southwest (Table 1). Within this gradient, the Baltic Sea can be divided into hydrographically distinct sub-basins, mostly separated by shallow sounds or sills. To strengthen the database with respect to higher salinity areas we additionally included a North Sea sub-basin adjacent to Kattegat, i.e. Skagerrak (salinity ca. 30; Table 1).

100 Table 1. Salinity and temperature in Swedish coastal areas, given as mean $( \pm \mathrm{SE})$ annual values per sub-basin across the years $1993-$ 2019. Values represent conditions by the bottom at 0-30 m depth based on data from the EU Copernicus Marine Service Information (CMEMS, 2021).

\begin{tabular}{lll}
\hline Sub-basin & Salinity & Temperature $\left({ }^{\circ} \mathbf{C}\right)$ \\
\hline Bothnian Bay & $2.68 \pm 0.01$ & $4.53 \pm 0.23$ \\
The Quark & $4.26 \pm 0.01$ & $5.38 \pm 0.25$ \\
Bothnian Sea & $5.10 \pm 0.01$ & $5.44 \pm 0.22$ \\
Åland Sea & $5.80 \pm 0.01$ & $6.44 \pm 0.25$ \\
N Baltic Proper & $6.37 \pm 0.01$ & $6.43 \pm 0.22$ \\
E Gotland Basin & $6.85 \pm 0.01$ & $7.30 \pm 0.24$ \\
W Gotland Basin & $6.88 \pm 0.01$ & $6.48 \pm 0.20$ \\
Bornholm Basin & $7.60 \pm 0.02$ & $8.15 \pm 0.24$ \\
Arkona Basin & $10.96 \pm 0.07$ & $8.92 \pm 0.26$ \\
The Sound & $23.42 \pm 0.14$ & $9.72 \pm 0.24$ \\
Kattegat & $29.02 \pm 0.05$ & $9.32 \pm 0.21$ \\
Skagerrak & $32.40 \pm 0.03$ & $9.62 \pm 0.22$
\end{tabular}

Reflecting its salinity conditions the Baltic Sea harbors a unique fish fauna with a mixture of freshwater species (e.g. pike, perch, pikeperch), and marine species (e.g. cod, herring; (Olsson et al., 2012). Further, many marine fish populations have 
https://doi.org/10.5194/bg-2021-302

Preprint. Discussion started: 2 December 2021

(c) Author(s) 2021. CC BY 4.0 License.

\section{(c) (i)}

105 adapted to the brackish conditions from their Atlantic counterparts (Laikre et al., 2005), for example Baltic cod and herring populations, and one flounder species is endemic to the Baltic Sea (Momigliano et al., 2018). Hence, the Baltic Sea may also have a unique value as a refuge for evolutionary lineages, and constitute an important genetic resource for management and conservation (Johannesson \& Andre, 2006).

\subsection{Species richness data}

110 The primary source of fish species data was the Swedish National database of coastal fish (www.slu.se/kul), which holds data from surveys encompassing coastal fish monitoring, mapping projects and surveillance programs over the entire salinity gradient of the Baltic Sea plus Skagerrak. Coastal areas were delineated using official national definition. Data from shallow depths $<30$ m were selected, corresponding to the main represented sampling methods in the database (Table S1), and with some margin to the photic depth in the concerned coastal habitat types (Kaskela et al., 2012). Only sampling occasions with

115 geographical coordinates and verified sampling references were included, giving 154,172 data entries, i.e. individual fish that had been caught and determined to species. The size of the coastal shallow areas ranged from $240 \mathrm{~km}^{2}$ (Åland Sea) to 5,798 $\mathrm{km}^{2}$ (Bothnian Bay; Table 2). Corresponding data from shallow offshore areas $(<30 \mathrm{~m}$ ) were also compiled for comparison (5,601 data entries). Further, additional data from 1) a national coastal trawl survey ( $n=4,420$ for coastal and $n=382$ for offshore areas), 2) the ICES-coordinated International Bottom Trawl Survey ( $n=1,969$ for coastal and $n=2,099$ for offshore areas) and

120 3) national projects using standardized methodology ( $n=893$ for coastal areas), all carried out in the Skagerrak, Kattegat and The Sound, were included, selecting only hauls from $<30 \mathrm{~m}$ depth within the concerned geographical delineations. Corresponding trawl data $(<30 \mathrm{~m})$ are not collected in Swedish waters of the other sub-basins.

Hence, data collected from multiple gears were combined, including gill nets, fyke nets, seines, trap nets, low impact underwater detonations and trawls, in order to maximize the chance of including different species (Table S1). The ambition to

125 collate information from all available fish surveys implied some differences in predominating data collection methods across the studied geographical range. The main data sources were trawls and trap net surveys in the most saline sub-basins, i.e. Skagerrak, Kattegat and The Sound, and gill net surveys in the remaining sub-basins (Table S1). The analytical approach was chosen to encompass this variability when making comparisons among sub-basins (see Sects. 2.3 and 4).

Observed SR, $\mathrm{SR}_{\mathrm{obs}}$, was reported for all sub-basins, but statistical analyses and comparisons were conducted only for sub-

130 basins containing data from at least 25 sampling/fishing occasions. This was the case for ten coastal sub-basins (Bothnian Bay, The Quark, Bothnian Sea, Åland Sea, N Baltic Proper, W Gotland Basin, Bornholm Basin, The Sound, Kattegat and Skagerrak), and one off-shore sub-basin (Kattegat). This dataset is referred to as "raw data", and contained 160,453 entries (i.e. fish individuals caught and determined to species) from 1,638 sampling/fishing occasions at 4,571 unique locations for shallow coastal areas, and 2,762 entries from 137 sampling/fishing occasions at 199 unique locations for shallow offshore 135 areas. 
https://doi.org/10.5194/bg-2021-302

Preprint. Discussion started: 2 December 2021

(c) Author(s) 2021. CC BY 4.0 License.

\section{(c) (i)}

Moreover, we searched for evidence of fish species that had remained undetected in our fish incidence database, by identifying fish species records from three additional sources, using the same criteria for geographical and depth delineations as above, i.e. 1) the SLU hosted national public database for citizens' reporting of species observations (SLU Swedish Species Information Centre, https://www.artportalen.se/; $n=8,926$ for coastal and $n=290$ for offshore areas after unreasonable species observations were discarded), 2) the national archive for oceanographic data hosted by the Swedish Meteorological and Hydrological Institute (SHARKweb, https:/www.smhi.se/en/services/open-data/national-archive-for-oceanographic-data; $n=1,259$ for coastal and $n=135$ for offshore areas), and 3) published inventory data for Swedish shallow coastal areas in Skagerrak, Kattegat and Bornholm Basin (Pihl \& Wennhage, 2002; Pihl et al., 1994; Wikström A., 2009). This "additional data sources" were used as complementary information on $\mathrm{SR}_{\mathrm{obs}}$ but could not be used in the statistical analysis since they only included presence-information for the reported species, rather than complete sampling and species incidence information. Further, our SR results were compared with the HELCOM (2020) checklist on macro-species containing information for all of the sub-basins and depths in the Baltic Sea region.

\subsection{Analysis of species richness data}

The raw data was first summarized to a dataset of unique fish species caught per fishing/sampling occasion in presence/absence format, and then further aggregated to an incidence frequency format, giving the observed total incidence of each species over the number of fishing/sampling occasions. This dataset is referred to as "fish incidence database". Each unique combination of a fishing/sampling location per date was defined as one sampling unit, and these were summed per sub-basin to obtain the sample sizes. Subsequently, incidence-based Hill diversity numbers of three orders, which differ in their propensity to include or exclude relatively rarer species (Hill, 1973), were calculated to quantify the species diversity of each assemblage, i.e. 1) species richness (SR), which counts all species equally irrespective theirincidence frequency, 2) Shannon diversity (ShD), which considers the incidence frequency and can be interpreted as the effective number of frequent species, and 3) Simpson diversity ( $\mathrm{SiD}$ ), which can be interpreted as the effective number of highly frequent species (Chao et al., 2014; Chao et al., 2020; Hill, 1973). Calculations were performed using the R package $i N E X T$ and the functions ChaoRichness, ChaoShannon and ChaoSimpson (Chao et al., 2020; Hsieh et al., 2016), and the Hill numbers are hereafter referred to as observed SR, ShD and $\mathrm{SiD}$, respectively. It should be noted that, using these methods, Shannon and Simpson diversity are expressed in terms of richness, i.e. number of species, which differs from other known formats.

$\mathrm{SR}_{\mathrm{obs}}$ is highly dependent on sample completeness (Colwell \& Coddington, 1994; Hill, 1973) and may typically underestimate the true SR due to undetected species (also referred to as under-sampling, sampling bias or sampling problem; Chao et al., 2014; Chao \& Jost, 2015; Menegotto \& Rangel, 2018). We used coverage-based rarefaction and extrapolation methods to

165 correct for this effect (Chao \& Jost, 2012). The Chao richness method, a non-parametric asymptotic richness estimator that is based on the frequency of rare species in the sample (Chao et al., 2014), was used to estimate the actual, asymptotic fish SR for each sub-basin (ChaoRichness function in the R package iNEXT; Hsieh et al., 2016), and the estimated parameters were 
https://doi.org/10.5194/bg-2021-302

Preprint. Discussion started: 2 December 2021

(c) Author(s) 2021. CC BY 4.0 License.

(c) (i)

interpreted as described and exemplified in (Chao et al., 2020). The respective values are hereafter referred to as estimated values (i.e. $\mathrm{SR}_{\text {est }}, \mathrm{ShD}_{\text {est }}$ and $\mathrm{SiD}_{\text {est }}$ ). Inventory (sample) completeness (IC) was calculated based on sample coverage (Chao \& Jost, 2012; Hsieh et al., 2016). To compare data across sub-basins, SR, ShD and SiD were standardized to the minimum observed IC across sub-basins (estimateD function in the R package $i N E X T$; Hsieh et al., 2016). The respective values are hereafter referred to as standardized values (i.e. $\mathrm{SR}_{\text {std }}, \mathrm{ShD}_{\text {std }}$ and $\mathrm{SiD}_{\text {std }}$ ). Similar analyses were also conducted for $\mathrm{SR}$ of fish with different functional attributes (see Sect. 2.4). All calculations were conducted using R version 4.0.4 (R Core Team, 2021).

\subsection{Fish functional attributes}

175 All observed fish species were assigned functional attributes based on ecological and behavioral traits, as well as into being of either marine or freshwater origin (Kullander, 2002). The affinity of each species to different parts of the coastal habitat, or habitat preference, was assigned based on (Elliott \& Dewailly, 1995; Pihl \& Wennhage, 2002), however with certain adaptations to suit both marine and brackish conditions (Table S3-S6). Applied categories were: Catadromous or anadromous migrants (CA), using coastal habitats only when migrating between marine and freshwaters for spawning and feeding; Marine juvenile migrants (MJ), using coastal habitats primarily as nursery or feeding grounds; Marine visitors (MV), occurring irregularly in the coastal area, having their primary habitat in deeper waters; Marine seasonal migrants (MS), making regular seasonal visits to coastal habitats, usually as adults; and Coastal residents (CR), spending almost their complete life cycle in coastal habitats or the littoral coastal zone. The main vertical distribution of each species in the water column, considering the adult stage, was assigned based on (Elliott \& Dewailly, 1995; Koli, 1990) as: Pelagic (P), living mainly in the water column;

185 Demersal (D), mainly associated with the bottom substrate; Demersal-pelagic (DP), alternating between the water column and bottom substrate; and Benthic (B), staying close to the seabed. Main feeding habits were assigned by combining information on feeding guild (Elliott \& Dewailly, 1995) with trophic levels (TL) and principal diet composition (Froese and Pauly, 2021), as: Piscivores (Pi; TL 3.6 - 4.4); Invertebrate and fish eaters (IF; TL 2.9 - 3.9); Invertebrate eaters (I; TL 2.8 - 3.9); Planktivores (PL; TL 3.1 - 3.2) and Omnivores (O; TL 2.8 - 3.5).

\subsection{Sea water salinity and temperature}

For each sub-basin, data on ambient salinity and temperature was extracted from the "Baltic Sea Physics Reanalysis" product, as calculated by the Swedish Meteorological and Hydrological Institute (SMHI) with the coupled physical-biochemical model system NEMO-SCOBI, and available from year 1993 (CMEMS, 2021). This encompassed full coverage layers with a $4 \mathrm{~km} \mathrm{x}$ $4 \mathrm{~km}$ grid. Monthly mean values close to the sea bed for all grid cells representing areas less than $30 \mathrm{~m}$ depth were first identified, and then used for calculating long-term means and standard deviations for the years 1993-2019. 
https://doi.org/10.5194/bg-2021-302

Preprint. Discussion started: 2 December 2021

(c) Author(s) 2021. CC BY 4.0 License.

(c) (i)

\subsection{Statistical analyses}

Linear regressions were used to analyze the relationships between salinity and temperature, respectively, and observed, standardized and estimated SR, ShD and SiD. To test for any additional explanatory effect of temperature, after accounting for the effect of salinity, we used ANOVA to compare models with salinity as the only explanatory factor with models with

200 salinity plus temperature as explanatory factors. Furthermore, relationships were tested between the different functional attributes and salinity. To reduce skewness and approximate normality, left-skewed response variables were $\log _{10}$-transformed prior to analysis, or, in two cases where the response variable included zero-values, Yeo-Johnson transformed (Yeo and Johnson, 2000). All analyses were conducted using R version 4.0.4 (R Core Team, 2021).

\section{Results}

\subsection{Salinity and temperature}

The annual mean salinity varied more than ten-fold in shallow coastal areas across the studied sub-basins, from 2.7 in the northernmost Baltic Sea to 32.4 in the Skagerrak. Across the same geographical range, the annual mean water temperature varied from $4.5^{\circ} \mathrm{C}$ in the north to ca. $9-10^{\circ} \mathrm{C}$ in the Sound and outwards (Table 1).

\subsection{Fish species observations and distribution}

$210 \mathrm{SR}_{\mathrm{obs}}$ varied from 23 (Arkona Basin) to 101 (Kattegat) in shallow coastal areas (Table 2, that also contains related information on e.g. sample size and species incidences per sub-basin), and amounted to 125 across sub-basins and years. Since IC was $<100 \%$ (see Sect. 3.3), this can be assumed a lower bound estimate of the true SR. Indeed, the additional data sources contained 19 more species that were not represented in the fish incidence database, resulting in a total fish $\mathrm{SR}_{\mathrm{obs}}$ of 144 in coastal areas (Table S3). Of the species in the fish incidence database, $49 \%$ occurred only in the higher salinity Skagerrak-Kattegat region 215 including The Sound, 15\% occurred only in the Baltic Sea region (i.e., inside The Sound), and 36\% occurred in both these regions. The most widely ranging speciescoastal area were herring (Clupea harengus), brown trout (Salmo trutta), European sprat (Sprattus sprattus) and eelpout (Zoarces viviparous), with incidences reported from all 12 sub-basins (Table S2).

For shallow offshore areas, $\mathrm{SR}_{\mathrm{obs}}$ varied from 11 (N Baltic Proper) to 74 (Kattegat; Table 2), and amounted to 96 across subbasins and years. The additional data sources contained information on 14 more species, resulting in a total fish $\mathrm{SR}_{\mathrm{obs}}$ of 110 220 (Table S3). Of the species in the fish incidence database, 48\% occurred only in the higher salinity Skagerrak-Kattegat region including The Sound, 21\% occurred only in the Baltic Sea region, and 31\% occurred in both regions. Herring was the only species reported in all the nine sub-basins for which fish incidence data for shallow offshore areas was available (Table S4). 
https://doi.org/10.5194/bg-2021-302

Preprint. Discussion started: 2 December 2021

(c) Author(s) 2021. CC BY 4.0 License.

Table 2. Summary information and statistics for the fish incidence database and additional data sources, representing the 12 subbasins and separately for Swedish shallow coastal and offshore areas $(<30 \mathrm{~m}$ depth: Observations and estimated inventory completeness (IC) are given for all sub-basins. Standardized (SR std) and estimated (SR $\mathbf{S}_{\text {est }}$ ) values were calculated for sub-basins with sample size $>25$ fishing/sampling occasions. SR std was calculated for an IC of $\mathbf{9 8 . 5 \%}$, which was the lowest IC among sub-basins with sufficient data (i.e. Åland Sea coastal areas: For comparison, $\mathbf{S R}_{\mathrm{obs}}$ if also including presence information from additional data sources (not included in the statistical analyses, see Sect. 2.2), and for whole sub-basins in the Baltic Sea according to HELCOM (2020, across countries and depths) are given as well. NA: not applicable; n.d.: not determined.

\begin{tabular}{|c|c|c|c|c|c|c|c|c|c|c|c|c|}
\hline \multirow[b]{2}{*}{ Sub-basin } & \multirow[b]{2}{*}{ Location } & \multirow[b]{2}{*}{$\begin{array}{l}\text { Size } \\
\text { of } \\
\text { area } \\
<30 \\
\text { m } \\
(\mathbf{k m} \\
\text { 2) }\end{array}$} & \multicolumn{5}{|c|}{ Species incidence data set } & \multicolumn{3}{|c|}{$\begin{array}{l}\text { Statistical } \\
\text { estimations }\end{array}$} & \multicolumn{2}{|c|}{ Additional data sources } \\
\hline & & & $\begin{array}{l}\text { Sample size } \\
\text { (i.e. } \\
\text { fishing/sampli } \\
\text { ng occasions) }\end{array}$ & $\begin{array}{l}\text { Species } \\
\text { incidence } \\
\mathbf{s}^{\mathbf{a}}\end{array}$ & $\begin{array}{l}\mathrm{SR}_{\mathbf{0}} \\
\text { bs }\end{array}$ & $\begin{array}{l}\text { Singleto } \\
\text { ns }\end{array}$ & $\begin{array}{l}\text { Doubleto } \\
\text { ns }\end{array}$ & $\begin{array}{l}\text { IC } \\
(\%)\end{array}$ & $\begin{array}{l}\text { SRst } \\
\text { d } \\
\text { (wit } \\
\text { h } \\
\text { CI) }\end{array}$ & $\begin{array}{l}\text { SRe } \\
\text { st }( \pm \\
\text { SE) } \\
\text { b }\end{array}$ & $\begin{array}{l}\text { SRobs plus } \\
\text { "species } \\
\text { presence" } \\
\text { observatio } \\
\text { ns from } \\
\text { additional } \\
\text { data } \\
\text { sources }\end{array}$ & $\begin{array}{l}\text { SR }_{\text {obs }} \text { all } \\
\text { countries } \\
\text { and depths } \\
(\text { HELCOM } \\
2020 \%\end{array}$ \\
\hline \multirow{2}{*}{$\begin{array}{l}\text { Bothnian } \\
\text { Bay }\end{array}$} & Coastal & 5798 & 70 & 553 & 29 & 4 & 0 & 99.3 & $24_{25}^{28}$ & $\begin{array}{l}35 \pm \\
7\end{array}$ & 34 & \multirow[t]{2}{*}{51} \\
\hline & Offshore & 1376 & 4 & 23 & 8 & 1 & 1 & n.d. & n.d. & n.d. & 11 & \\
\hline \multirow[t]{2}{*}{ The Quark } & Coastal & 1350 & 71 & 754 & 30 & 4 & 2 & 99.5 & $26_{24}^{28}$ & $\begin{array}{l}34 \pm \\
5\end{array}$ & 35 & \multirow[t]{2}{*}{56} \\
\hline & Offshore & 356 & NA & NA & NA & NA & NA & NA & NA & NA & NA & \\
\hline \multirow{2}{*}{$\begin{array}{l}\text { Bothnian } \\
\text { Sea }\end{array}$} & Coastal & 2986 & 194 & 2222 & 42 & 2 & 0 & 99.9 & $37_{36}^{38}$ & $\begin{array}{l}43 \pm \\
2\end{array}$ & 50 & \multirow[t]{2}{*}{74} \\
\hline & Offshore & 918 & 17 & 87 & 24 & 5 & 3 & n.d. & n.d. & n.d. & 24 & \\
\hline \multirow[t]{2}{*}{ Åland Sea } & Coastal & 240 & 31 & 394 & 32 & 6 & 3 & $\begin{array}{l}98.5 \\
*\end{array}$ & $\begin{array}{l}32_{28}^{35} \\
*\end{array}$ & $\begin{array}{l}38 \pm \\
6\end{array}$ & 45 & \multirow[t]{2}{*}{71} \\
\hline & Offshore & 28 & NA & NA & NA & NA & NA & NA & NA. & NA & NA & \\
\hline \multirow{2}{*}{$\begin{array}{l}\text { N Baltic } \\
\text { Proper }\end{array}$} & Coastal & 2156 & 77 & 1046 & 42 & 6 & 3 & 99.4 & $36_{34}^{38}$ & $\begin{array}{l}48 \pm \\
6\end{array}$ & 56 & \multirow[t]{2}{*}{67} \\
\hline & Offshore & 218 & 4 & 11 & 4 & 0 & 2 & n.d. & n.d. & n.d. & 5 & \\
\hline E Gotland & Coastal & 936 & 13 & 94 & 25 & 8 & 5 & n.d. & n.d. & n.d. & 37 & \multirow{2}{*}{82} \\
\hline Basin & Offshore & 2148 & 6 & 45 & 14 & 4 & 3 & n.d. & n.d. & n.d. & 14 & \\
\hline $\begin{array}{l}\text { W } \\
\text { Gotland }\end{array}$ & Coastal & 5382 & 411 & 5123 & 53 & 6 & 2 & 99.9 & $39_{38}^{40}$ & $\begin{array}{l}62 \pm \\
10\end{array}$ & 60 & \multirow[t]{3}{*}{67} \\
\hline Basin & Offshore & 1525 & 4 & 20 & 7 & 1 & 2 & n.d. & n.d. & n.d. & 8 & \\
\hline $\begin{array}{l}\text { Bornholm } \\
\text { Basin }\end{array}$ & Coastal & 972 & 68 & 837 & 46 & 5 & 1 & 99.4 & $42_{40}^{44}$ & $\begin{array}{l}58 \pm \\
17\end{array}$ & 59 & \\
\hline
\end{tabular}


https://doi.org/10.5194/bg-2021-302

Preprint. Discussion started: 2 December 2021

(c) Author(s) 2021. CC BY 4.0 License.

\begin{tabular}{|c|c|c|c|c|c|c|c|c|c|c|c|c|}
\hline & Offshore & 2213 & 14 & 121 & 28 & 8 & 6 & n.d. & n.d. & n.d. & 31 & 104 \\
\hline Arkona & Coastal & 297 & 7 & 67 & 23 & 7 & 7 & n.d. & n.d. & n.d. & 37 & 110 \\
\hline Basin & Offshore & 1390 & 17 & 234 & 30 & 7 & 5 & n.d. & n.d. & n.d. & 30 & 110 \\
\hline \multirow[t]{2}{*}{ The Sound } & Coastal & 380 & 119 & 1373 & 61 & 8 & 4 & 99.4 & $54_{51}^{57}$ & $\begin{array}{l}69 \pm \\
7\end{array}$ & 70 & \multirow[t]{2}{*}{144} \\
\hline & Offshore & NA & NA & NA & NA & NA & NA & NA & NA & NA & NA & \\
\hline \multirow{2}{*}{ Kattegat } & Coastal & 1906 & 353 & 6012 & 101 & 11 & 8 & 99.8 & $78_{76}^{80}$ & $\begin{array}{l}109 \\
\pm 6\end{array}$ & 114 & \multirow{2}{*}{178} \\
\hline & Offshore & 1304 & 137 & 2039 & 74 & 15 & 12 & 99.3 & $64_{59}^{68}$ & $\begin{array}{l}83 \pm \\
6\end{array}$ & 77 & \\
\hline \multirow[t]{2}{*}{ Skagerrak } & Coastal & 1085 & 230 & 3195 & 69 & 13 & 3 & 99.6 & $52_{50}^{53}$ & $\begin{array}{l}90 \pm \\
16\end{array}$ & 106 & \multirow[t]{2}{*}{ NA } \\
\hline & Offshore & 80 & 5 & 65 & 30 & 14 & 6 & n.d. & n.d. & n.d. & 60 & \\
\hline
\end{tabular}

${ }^{\text {a }}$ Sum of the number of species observed across all sampling occasions. Please note that this does not correspond to "entries" in Sect. 2.2, which is individual fish caught and determined to species.

${ }^{\mathrm{b}}$ Considered a lower bound estimate (Chao et al., 2020)

\subsection{Inventory completeness}

235 The fish species IC in shallow coastal areas varied from $98.5 \%$ in the Åland Sea to $99.9 \%$ in the W Gotland Basin and the Bothnian Sea, based on analysis of data from the ten sub-basins with a sample size $>25$ fishings/samplings, suggesting that ca. $0.1-1.5 \%$ of statistically likely existing species remained undetected (Table 2). The species accumulation curves (SAC) show the $\mathrm{SR}_{\mathrm{obs}}$ at the conducted sample sizes, and SR estimated for hypothetical smaller and larger sample sizes, including $95 \%$ confidence intervals. According to these, the steepest increase of accumulated species occurred with the first ca. 20 samplings

240 in all sub-basins, and coastal fish SR was highest in the Kattegat, followed by the Skagerrak and The Sound, and lowest in the other seven sub-basins (i.e. confidence intervals not overlapping, Fig. 1a).

The SAC's also visualize differences in IC between sub-basins. For the three most saline sub-basins, Skagerrak, Kattegat and The Sound, the SACs were still clearly increasing with increasing sample size even when extrapolating to double the actual sample size. Hence, $\mathrm{SR}_{\mathrm{est}}$ for these sub-basins are more uncertain and more likely biased low than for sub-basins where the 245 curve flattened, illustrating a more complete inventory, e.g. W Gotland Basin and The Bothnian Sea (Fig. 1a). SR est, estimated based on extrapolation of the information in the fish incidence database, were similar to $\mathrm{SR}_{\mathrm{obs}}$ if complementing the incidence data with records from the additional data sources (Table 2). 


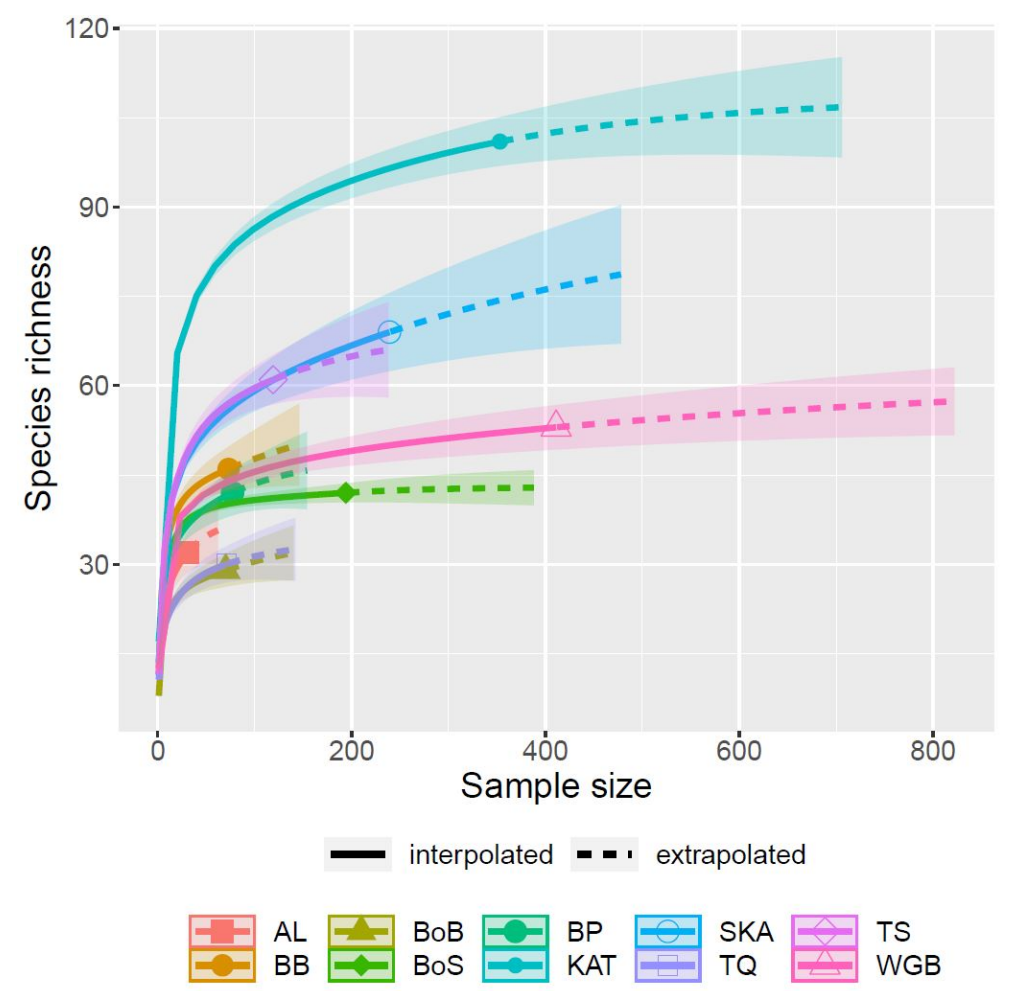

250 Figure 1. Sample-size-based sampling curves with $95 \%$ confidence intervals (shaded areas), showing rarefaction/interpolation (solid) and extrapolation (dotted) line segments for (a) species richness (SR), (b) Shannon diversity (the effective number of frequent species in the assemblage, $\mathrm{ShD}$ ) and (c) Simpson diversity (the effective number of very frequent species in the assemblage, SiD) of fish in coastal areas of the $\mathbf{1 0}$ analyzed sub-basins. The intersection points between solid and dotted lines represent the observed values. Legend acronyms are AL: Åland Sea, BB: Bornholm Basin, BoB: Bothnian Bay, BoS: Bothnian Sea, BP: N Baltic Proper, KAT: Kattegat, SKA: Skagerrak, TQ: The Quark, TS: The Sound and WGB: W Gotland Basin.

For shallow offshore areas, only one sub-basin had enough data to conduct statistical rarefaction and extrapolation (i.e., Kattegat, Table 2). IC amounted to $99.3 \%$, and also here $\mathrm{SR}_{\mathrm{est}}$ was similar to $\mathrm{SR}_{\mathrm{obs}}$ when incidence data and species presence information from additional sources were combined (Table 2). A comparison of $\mathrm{SR}_{\text {est }}$ offshore areasuggests that, in Kattegat,

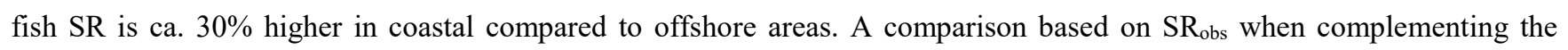
incidence data with additional data sources suggests ca. 50\% higher SR in the coastal compared to offshore shallow Kattegat waters (Table 2). 
https://doi.org/10.5194/bg-2021-302

Preprint. Discussion started: 2 December 2021

(c) Author(s) 2021. CC BY 4.0 License.

Table 3. Shannon diversity (ShD) and Simpson diversity (SiD) for coastal and offshore areas. Calculated values are given for all subbasins, and standardized (std) and estimated (est) values are given for the sub-basins with a sample size $\geq 25$ fishings/samplingsShD gives the effective number of frequent species (the exponential of Shannon's entropy index), and SiD the effective number of highly frequent species (the inverse of Simpson's concentration index) in the assemblage (Chao et al. 2020, Chao et al. 2014). NA: not applicable; n.d.: not determined.

\begin{tabular}{|c|c|c|c|c|c|c|c|c|c|}
\hline \multirow[b]{2}{*}{ Sub-basin } & \multirow[b]{2}{*}{ Area } & \multicolumn{4}{|c|}{ Shannon Diversity } & \multicolumn{4}{|c|}{ Simpson diversity } \\
\hline & & $\begin{array}{l}\text { Calculated } \\
\text { ShD }\end{array}$ & $\begin{array}{l}\text { ShD std } \\
\text { lower } \\
\text { limits) }\end{array}$ & $\begin{array}{r}\text { with upper and } \\
\text { confidence }\end{array}$ & $\begin{array}{l}\text { ShD est } \\
( \pm \text { SE })\end{array}$ & $\begin{array}{l}\text { Calculated } \\
\text { SiD }\end{array}$ & $\begin{array}{l}\text { SiD std } \\
\text { lower } \\
\text { limits) }\end{array}$ & $\begin{array}{r}\text { ith upper and } \\
\text { confidence }\end{array}$ & $\begin{array}{l}\text { SiD est } \\
( \pm \mathrm{SE})\end{array}$ \\
\hline Bothnian & Coastal & 19 & & $19_{18}^{20}$ & $20 \pm 1$ & 16 & & $16_{15}^{17}$ & $16 \pm 1$ \\
\hline Bay & Offshore & 8 & n.d. & & n.d. & 7 & n.d. & & n.d. \\
\hline The Quark $^{\mathrm{a}}$ & Coastal & 18 & & $18_{17}^{18}$ & $18 \pm 1$ & 15 & & $15_{14}^{16}$ & $15 \pm 0.3$ \\
\hline Bothnian & Coastal & 28 & & $27_{26}^{28}$ & $28 \pm 0.4$ & 23 & & $23_{22}^{23}$ & $23 \pm 0.4$ \\
\hline Sea & Offshore & 20 & n.d. & & n.d. & 18 & n.d. & & n.d. \\
\hline Åland Sea ${ }^{\mathrm{a}}$ & Coastal & $21^{*}$ & & $22_{20}^{22} *$ & $22 \pm 1$ & $18^{*}$ & $18_{17}^{19 *}$ & & $18 \pm 1$ \\
\hline N Baltic & Coastal & 26 & & $25_{24}^{26}$ & $26 \pm 1$ & 22 & & $22_{21}^{22}$ & $22 \pm 0.4$ \\
\hline Proper & Offshore & 4 & n.d. & & n.d. & 4 & n.d. & & n.d. \\
\hline E Gotland & Coastal & 18 & n.d. & & n.d. & 15 & n.d. & & n.d. \\
\hline Basin & Offshore & 12 & n.d. & & n.d. & 10 & n.d. & & n.d. \\
\hline W Gotland & Coastal & 31 & & $29_{29}^{30}$ & $31 \pm 0.2$ & 26 & & $25_{25}^{26}$ & $26 \pm 0.3$ \\
\hline Basin & Offshore & 6 & n.d. & & n.d. & 6 & n.d. & & n.d. \\
\hline Bornholm & Coastal & 32 & & $31_{30}^{32}$ & $33 \pm 1$ & 27 & & $26_{25}^{27}$ & $27 \pm 1$ \\
\hline Basin & Offshore & 19 & n.d. & & n.d. & 15 & n.d. & & n.d. \\
\hline Arkona & Coastal & 18 & n.d. & & n.d. & 15 & n.d. & & n.d. \\
\hline Basin & Offshore & 21 & n.d. & & n.d. & 18 & n.d. & & n.d. \\
\hline The Sound ${ }^{\mathrm{a}}$ & Coastal & 34 & & $33_{32}^{34}$ & $35 \pm 1$ & 26 & & $25_{24}^{26}$ & $26 \pm 1$ \\
\hline Kattegat & Coastal & 51 & & $49_{48}^{50}$ & $51 \pm 1$ & 38 & & $37_{37}^{38}$ & $38 \pm 0.4$ \\
\hline Nallo gat & Offshore & 32 & & $31_{30}^{33}$ & $33 \pm 1$ & 24 & & $24_{24}^{25}$ & $25 \pm 0.4$ \\
\hline Skroerrok & Coastal & 33 & & $32_{31}^{33}$ & $34 \pm 1$ & 25 & & $25_{24}^{26}$ & $25 \pm 0.3$ \\
\hline & Offshore & 25 & n.d. & & n.d. & 22 & n.d. & & n.d. \\
\hline
\end{tabular}

${ }^{\mathrm{a}}$ No offshore areas occur in these sub-basins.

\subsection{Shannon and Simpson diversity}

270 Rarefaction and extrapolation SACs carried out for Shannon diversity (ShD) show that the effective number of frequently recorded fish species was quite well captured by the samplings in all analyzed sub-basins, illustrated by SACs with small remaining slopes at extrapolated higher sample size. As for $\mathrm{SR}_{\mathrm{obs}}$, $\mathrm{ShD}$ was highest in Kattegat, while the remaining nine subbasins clustered in two separate groups. The lowest ShD's were noted for the Åland Sea, The Quark and Bothnian Bay (Fig. 
https://doi.org/10.5194/bg-2021-302

Preprint. Discussion started: 2 December 2021

(c) Author(s) 2021. CC BY 4.0 License.

(c) (i)

1b, Table 3). The effective number of highly frequent species, i.e. Simpson diversity (SiD), was also well captured in all subbasins, being highest in Kattegat, while SiD in the remaining sub-basins clustered in four groups (Fig. 1c, Table 3).

\subsection{Standardized and estimated species richness}

To compare coastal fish SR, ShD and SiD across sub-basins, we estimated their standardized values against the minimum observed IC in any of the sub-basins. This represented a standardization to the IC of the Arkona Basin data (98.5\%; Tables 2 and 3). $\mathrm{SR}_{\mathrm{std}}$ was ca. three times higher in the relatively more saline Kattegat $\left(\mathrm{SR}_{\mathrm{std}}=78\right)$ compared to the least saline Bothnian Bay $\left(\mathrm{SR}_{\text {std }}=24\right)$, as also confirmed by comparing the respective $\mathrm{SR}_{\text {est }}$ values (Table 2). The differences were smaller for $\mathrm{ShD}$ and $\mathrm{SiD}$. For example, based on $\mathrm{SiD}_{\text {std }}$ and $\mathrm{SiD}_{\text {est }}$, the effective number of highly frequent species was ca. two times higher in coastal areas of the Kattegat compared to the Bothnian Bay (Table 3). This implies, as also seen from the SACs (Fig. 1), that the frequent and most frequent fish species were captured quite well by the samplings for all sub-basins, and that remaining uncertainties in differences across the salinity gradient is mostly due to uncertainty in the numbers of rare and very rare fish species.

\subsection{Relationships of SR with salinity and temperature}

Species richness increased with increasing mean water salinity, which explained 37-55\% of the variance in the data based on $\mathrm{SR}_{\mathrm{obs}}, \mathrm{ShD}_{\text {obs }}$ and $\mathrm{SiD}_{\text {obs. }}$. Using the standardized or estimated values, i.e. values corrected for sample size, resulted in stronger correlations, i.e. higher explained variance (40-77\%; Fig. 2, Table 4). $\mathrm{SR}_{\mathrm{obs}}, \mathrm{ShD}_{\mathrm{obs}}$ and $\mathrm{SiD}_{\mathrm{obs}}$ were not correlated with mean water temperature, but, using the standardized and estimated values, correlations with temperature were also significant (explaining 48-77\% of the variance; Fig. 2, Table 4). The slope estimates of the linear regressions differed more across observed, standardized and estimated values for SR than for ShD and SiD (Fig. 2, Table 4). In all cases, adding temperature as explanatory variable to the regression models with salinity as explanatory variable did not improve the model (all $P>0.14$ ).

\subsection{Fish functional attributes}

$74 \%$ and $26 \%$ of the fish species recorded in shallow coastal areas were of marine and freshwater origin, respectively (based on the incidence data, i.e. $\mathrm{SR}_{\mathrm{obs}}$ of 92 vs. 33 species; Table S2). In the most saline sub-basins, i.e. Skagerrak and Kattegat, the $\mathrm{SR}_{\text {std }}$ of marine fish species was seven to ten times higher than that of freshwater fish species. The $\mathrm{SR}_{\text {std }}$ of marine vs. freshwater fish were rather similar in the central Baltic Sea, while in the northernmost and least saline sub-basins, i.e. Bothnian Sea, The Quark and Bothnian Bay, the $\mathrm{SR}_{\text {std }}$ of freshwater fish species exceeded the $\mathrm{SR}_{\text {std }}$ of marine fish species by two to three times. 300 In total, the marine fish $\mathrm{SR}_{\text {std }}$ decreased by a factor of 8-11 along the salinity gradient, from 39 and 57 marine species ( $\left.\mathrm{SR}_{\mathrm{std}}\right)$ in Skagerrak and Kattegat to 5 in the Bothnian Bay. Freshwater fish SR std increased by a factor of 2-4 along the same gradient (Fig. 3, Table S2). These distributional patterns of freshwater vs. marine fish species were also reflected by negative univariate 
https://doi.org/10.5194/bg-2021-302

Preprint. Discussion started: 2 December 2021

(c) Author(s) 2021. CC BY 4.0 License.

correlations of freshwater SR (obs, std and est) with salinity, and positive univariate correlations of marine SR with salinity (Fig. S1, Table 5).

305 Table 4. Statistical indicators for the correlations between fish species richness (SR), Shannon Diversity (ShD) and Simpson Diversity (SiD), and salinity or annual mean water temperature in coastal areas of the studied sub-basins. The linear regressions were carried out separately for observed (obs), standardized (std) and estimated (est) values in each case. n.s.=not significant.

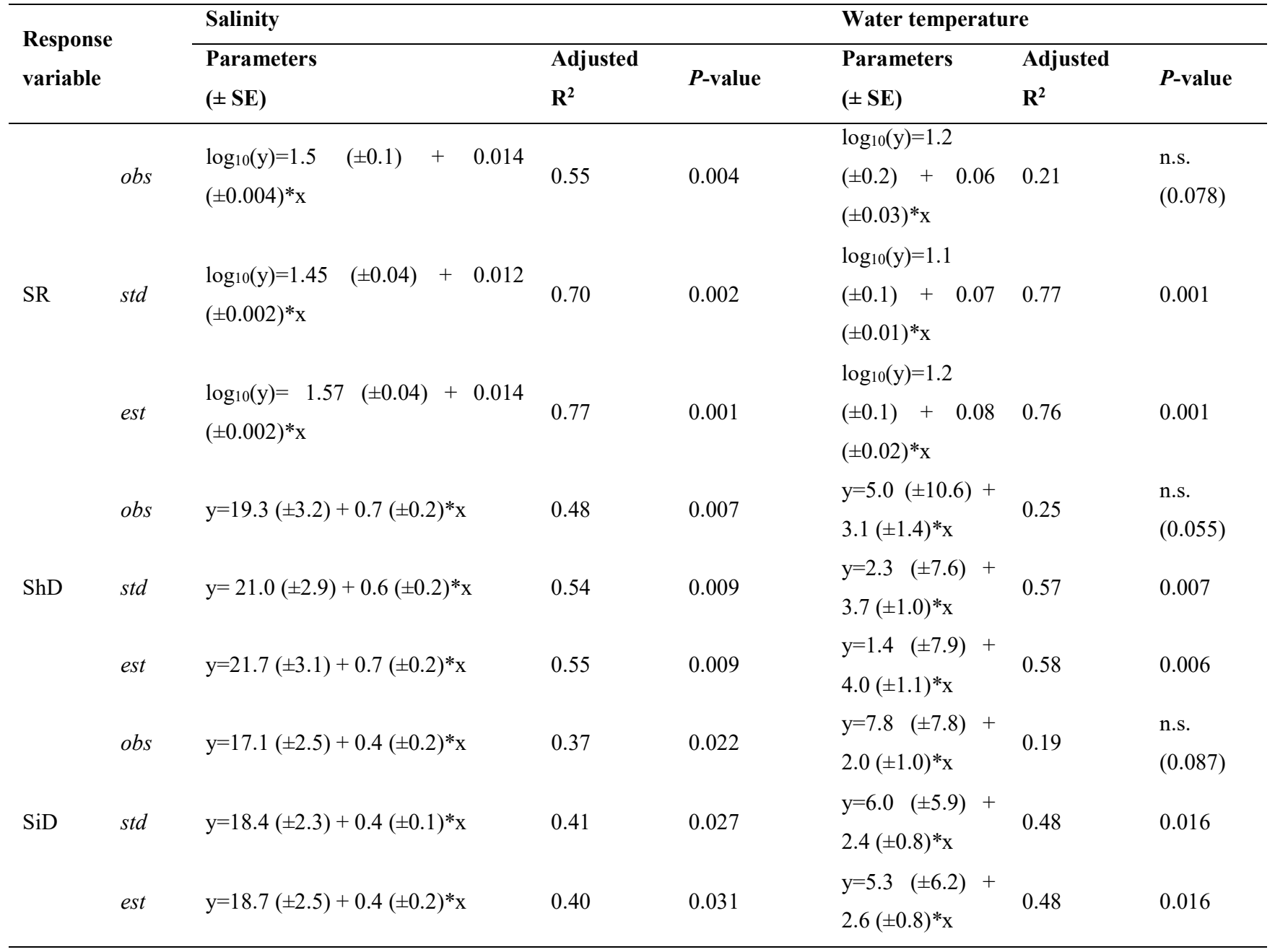

Concerning habitat preference, half of the fish species in Swedish shallow coastal areas were classified as being coastal resident species (CR; based on incidence data only, $\mathrm{SR}_{\mathrm{obs}}$ : 63 species, Table $\mathrm{S} 2$ ). This group dominated coastal fish assemblages in all sub-basins, with CR SR std of 19-30 across sub-basins (Fig. 4, Table S2), and was not linearly related to salinity (Table 5). A similar result was noted for catadromous or anadromous fish species, with $\mathrm{SR}_{\text {std }}$ between 2 and 6 in each sub-basin that was not related to salinity (Tables S2, 5). In the more saline sub-basins, fish species classified as marine visitors or as marine juvenile or seasonal migrants contributed significant numbers to the $\mathrm{SR}_{\text {std, }}$ while these species groups did not exist or 315 contributed only little to the $\mathrm{SR}_{\text {std }}$ in the Baltic Sea region (Fig. 4, Table S2). Reflecting this pattern, the SR of marine migrating 
or visiting fish species (i.e. MJ, MS and MV) was significantly positively related to salinity in most cases, with the strongest correlations for marine juvenile visitors (MJ; Fig. S2, Table 5).
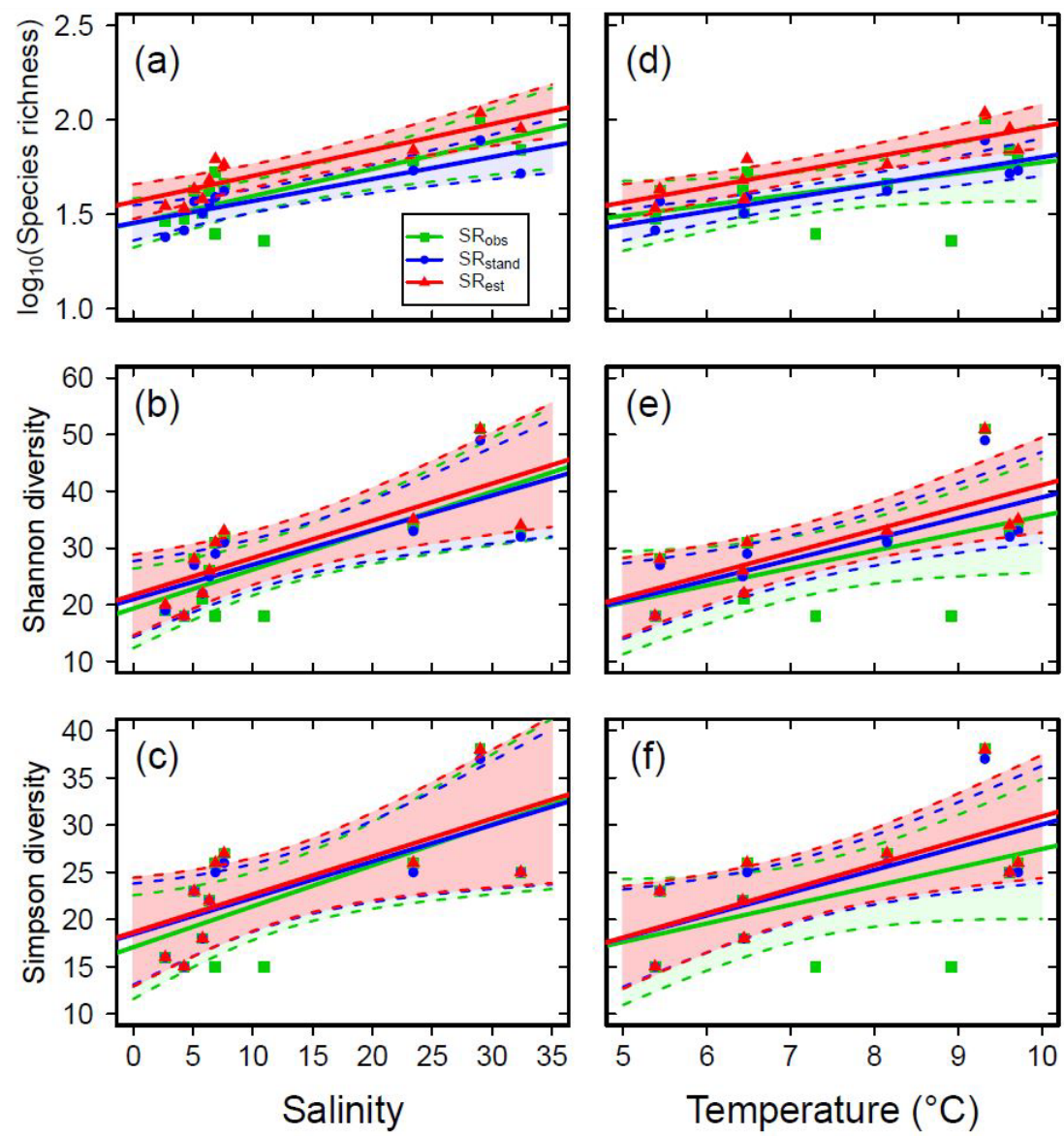

Figure 2. Scatterplots of the fish species richness estimates against mean salinity (left column) and mean water temperature (right column), with total species richness (log 10 -transformed; a and d), Shannon diversity (effective number of frequent species; b and e) and Simpson diversity (effective number of highly frequent species; $\mathrm{c}$ and $\mathrm{f}$ : Each plot shows the observed, standardized and estimated values, and, when significant $(P<0.05)$, the linear regression lines (solid) and $95 \%$-confidence intervals (shaded areas surrounded by dashed lines: The different lines and shaded confidence intervals are partly overlying each other within the panels in some cases, indicating very similar regression statistics. For regression equations and statistics, see Table 4.

325 Concerning vertical distribution, benthic fish species (B) were important contributors to $\mathrm{SR}_{\text {std }}$ in the sub-basins of higher salinity, but only few or no fish species belonged to this group in the less saline sub-basins (Fig. 5; Table S2). A similar, though less pronounced, distribution pattern was also found for demersal fish species (D). Accordingly, the SR of these groups were positively related to salinity in all cases (i.e. for $\mathrm{SR}_{\mathrm{obs}}, \mathrm{SR}_{\text {std }}$ and $\mathrm{SR}_{\text {est }}$, Fig. S3; Table 5). The $\mathrm{SR}$ of demersal-pelagic (DP) fish species varied between sub-basins with a $\mathrm{SR}_{\text {std }}$ of 6-16, not related to salinity. A similar picture was found for pelagic fish species (P), where $\mathrm{SR}_{\text {std }}$ varied between 5-12 across sub-basins (Fig. 5, Table S2) and was not related to salinity (Fig. S3, Table $5)$. 
https://doi.org/10.5194/bg-2021-302

Preprint. Discussion started: 2 December 2021

(c) Author(s) 2021. CC BY 4.0 License.

The two most common feeding groups observed in shallow coastal areas, across all sub-basins, were invertebrate and fish eating species (IF) as well as invertebrate feeders (I). The third-most represented feeding group was piscivorous fish species (Pi), followed by planktivorous and omnivorous species in lower and often similar SR std $_{\text {(Fig. 6, Table S2). SR }}$ std of Pi and IF 335 increased with increasing salinity, and $\mathrm{SR}_{\text {std }}$ and $\mathrm{SR}_{\mathrm{est}}$ of I increased with increasing salinity (Fig. S4, Table 5).

Table 5. Statistical relationships between observed (obs), standardized (std) and estimated (est) SR for fish functional attributes in Swedish shallow coastal areas and salinity. When YJ(y), the response variable was Yeo-Johnson transformed (Yeo and Johnson, 2000). n.s. =not significant.

\begin{tabular}{|c|c|c|c|c|c|}
\hline Response variable & & & Parameters $( \pm$ SE) & $\mathbf{R}^{2}$ & $P$-value \\
\hline \multirow{6}{*}{ Origin } & \multirow{3}{*}{ Marine } & obs & $\log _{10}(y)=1.0( \pm 0.1)+0.03( \pm 0.01)^{*} x$ & 0.74 & $<0.001$ \\
\hline & & std & $\log _{10}(y)=0.9( \pm 0.1)+0.03( \pm 0.01)^{*} x$ & 0.71 & 0.001 \\
\hline & & est & $\log _{10}(y)=1.1( \pm 0.1)+0.03( \pm 0.01) * x$ & 0.66 & 0.003 \\
\hline & \multirow{3}{*}{ Freshwater } & $o b s$ & $y=22.0( \pm 3.0)-0.6( \pm 0.2)^{*} x$ & 0.39 & 0.018 \\
\hline & & std & $y=19.0( \pm 1.1)-0.4( \pm 0.1) * x$ & 0.84 & $<0.001$ \\
\hline & & est & $y=25.4( \pm 2.5)-0.5( \pm 0.2)^{*} x$ & 0.47 & 0.017 \\
\hline \multirow{15}{*}{ Habitat preference } & \multirow{3}{*}{$\mathrm{CR}$} & $o b s$ & $y=25.3( \pm 4.6)+0.1( \pm 0.3) * x$ & $-0.08^{\mathrm{a}}$ & n.s. $(0.661)$ \\
\hline & & std & $y=26.5( \pm 2.0)-0.1( \pm 0.1)^{*} x$ & $-0.04^{\mathrm{a}}$ & n.s. $(0.538)$ \\
\hline & & est & $y=32.5( \pm 3.0)+0.1( \pm 0.2) * x$ & $-0.10^{\mathrm{a}}$ & n.s. $(0.665)$ \\
\hline & \multirow{3}{*}{$\mathrm{CA}$} & $o b s$ & $\log _{10}(y)=0.4( \pm 0.1)+0.01( \pm 0.01)^{*} x$ & $-0.10^{\mathrm{a}}$ & n.s. $(0.351)$ \\
\hline & & std & $\log _{10}(y)=0.5( \pm 0.1)+0.005( \pm 0.004)^{*} x$ & $-0.10^{\mathrm{a}}$ & n.s. $(0.314)$ \\
\hline & & est & $\log _{10}(y)=0.5( \pm 0.1)+0.006( \pm 0.005)^{*} x$ & $-0.10^{\mathrm{a}}$ & n.s. $(0.287)$ \\
\hline & \multirow{3}{*}{ MJ } & obs & $\log _{10}(y)=0.14( \pm 0.13)+0.04( \pm 0.01)^{*} x$ & 0.60 & 0.002 \\
\hline & & std & $\log _{10}(y)=0.57( \pm 0.09)+0.016( \pm 0.004) * x$ & 0.69 & 0.025 \\
\hline & & est & $\log _{10}(y)=0.43( \pm 0.07)+0.018( \pm 0.004) * x$ & 0.84 & 0.007 \\
\hline & \multirow{3}{*}{ MS } & obs & $y=0.7( \pm 0.6)+0.3( \pm 0.04) * x$ & 0.79 & $<0.001$ \\
\hline & & std & $y=2.4( \pm 1.0)+0.2( \pm 0.1)^{*} x$ & 0.67 & 0.029 \\
\hline & & est & $y=3.0( \pm 1.4)+0.2( \pm 0.1)^{*} x$ & 0.55 & n.s. $(0.056)$ \\
\hline & \multirow{3}{*}{ MV } & obs & $Y J(y)=-1.0( \pm 0.2)+0.09( \pm 0.01) * x$ & 0.81 & $<0.001$ \\
\hline & & std & $y=-3.4( \pm 7.1)+0.7( \pm 0.3) * x$ & 0.65 & n.s. $(0.123)$ \\
\hline & & est & $y=-6.5( \pm 10.8)+1.3( \pm 0.4)^{*} x$ & 0.72 & n.s. $(0.100)$ \\
\hline \multirow{8}{*}{ Vertical distribution } & \multirow{3}{*}{ B } & $o b s$ & $\mathrm{YJ}(\mathrm{y})=-1.0( \pm 0.2)+0.09( \pm 0.01) * \mathrm{x}$ & 0.76 & $<0.001$ \\
\hline & & std & $\log _{10}(y)=0.3( \pm 0.1)+0.031( \pm 0.004)^{*} x$ & 0.91 & 0.001 \\
\hline & & est & $\log _{10}(y)=0.4( \pm 0.1)+0.039( \pm 0.004) * x$ & 0.95 & $<0.001$ \\
\hline & \multirow{3}{*}{$\mathrm{D}$} & obs & $\log _{10}(y)=1.0( \pm 0.1)+0.02( \pm 0.01)^{*} x$ & 0.44 & 0.011 \\
\hline & & std & $\log _{10}(y)=0.97( \pm 0.04)+0.013( \pm 0.013) * x$ & 0.70 & 0.002 \\
\hline & & est & $\log _{10}(y)=1.1( \pm 0.1)+0.014( \pm 0.004) * x$ & 0.54 & 0.010 \\
\hline & \multirow{2}{*}{ DP } & $o b s$ & $y=13.1( \pm 2.1)-0.1( \pm 0.1)^{*} x$ & $-0.10^{\mathrm{a}}$ & n.s. $(0.679)$ \\
\hline & & std & $y=13.9( \pm 1.3)-0.1( \pm 0.1)^{*} x$ & 0.16 & n.s. $(0.136)$ \\
\hline
\end{tabular}


https://doi.org/10.5194/bg-2021-302

Preprint. Discussion started: 2 December 2021

(c) Author(s) 2021. CC BY 4.0 License.

\begin{tabular}{|c|c|c|c|c|c|}
\hline & & est & $y=15.5( \pm 1.8)-0.03( \pm 0.11) * x$ & $-0.12^{\mathrm{a}}$ & n.s. $(0.792)$ \\
\hline & & $o b s$ & $\log _{10}(y)=0.8( \pm 0.1)+0.006( \pm 0.004) * x$ & 0.07 & n.s. $(0.203)$ \\
\hline & P & std & $\log _{10}(y)=0.80( \pm 0.05)+0.004( \pm 0.003) * x$ & 0.06 & n.s. $(0.243)$ \\
\hline & & est & $\log _{10}(y)=0.9( \pm 0.1)+0.008( \pm 0.004) * x$ & 0.27 & $\begin{array}{l}\text { n.s. } \\
(0.072)\end{array}$ \\
\hline & & $o b s$ & $\log _{10}(y)=0.70( \pm 0.06)+0.018( \pm 0.004) * x$ & 0.63 & 0.001 \\
\hline & $\mathrm{Pi}$ & std & $\log _{10}(y)=0.69( \pm 0.06)+0.014( \pm 0.004) * x$ & 0.64 & 0.004 \\
\hline & & est & $\log _{10}(y)=0.76( \pm 0.06)+0.020( \pm 0.004) * x$ & 0.77 & 0.001 \\
\hline & & $o b s$ & $y=8.7( \pm 1.8)+0.7( \pm 0.1) * x$ & 0.75 & $<0.001$ \\
\hline & IF & std & $y=9.9( \pm 1.1)+0.4( \pm 0.1) * x$ & 0.81 & $<0.001$ \\
\hline & & est & $y=10.7( \pm 1.9)+0.8( \pm 0.1)^{*} x$ & 0.84 & $<0.001$ \\
\hline & & $o b s$ & $\log _{10}(y)=0.8( \pm 0.2)+0.02( \pm 0.01) * x$ & 0.16 & n.s. $(0.108)$ \\
\hline Feeding habit & I & std & $\log _{10}(y)=0.85( \pm 0.04)+0.015( \pm 0.003) * x$ & 0.79 & $<0.001$ \\
\hline & & est & $\log _{10}(y)=0.93( \pm 0.04)+0.018( \pm 0.002) * x$ & 0.86 & $<0.001$ \\
\hline & & obs & $\log _{10}(y)=0.5( \pm 0.1)+0.007( \pm 0.004) * x$ & 0.12 & n.s. $(0.142)$ \\
\hline & PL & std & $\log _{10}(y)=0.4( \pm 0.1)+0.008( \pm 0.003) * x$ & 0.36 & 0.041 \\
\hline & & est & $\log _{10}(y)=0.5( \pm 0.1)+0.007( \pm 0.004) * x$ & 0.20 & n.s. $(0.108)$ \\
\hline & & $o b s$ & $y=3.6( \pm 0.9)-0.1( \pm 0.1) * x$ & $-0.03^{\mathrm{a}}$ & n.s. $(0.419)$ \\
\hline & $\mathrm{O}$ & std & $y=3.2( \pm 0.5)+0.1( \pm 0.04) * x$ & 0.23 & n.s. $(0.131)$ \\
\hline & & est & $y=3.5( \pm 0.5)+0.1( \pm 0.04) * x$ & 0.33 & n.s. $(0.080)$ \\
\hline
\end{tabular}

${ }^{\text {a Adjusted }} \mathrm{R}^{2}$ can turn negative for multiple $\mathrm{R}^{2}$ close to zero. 


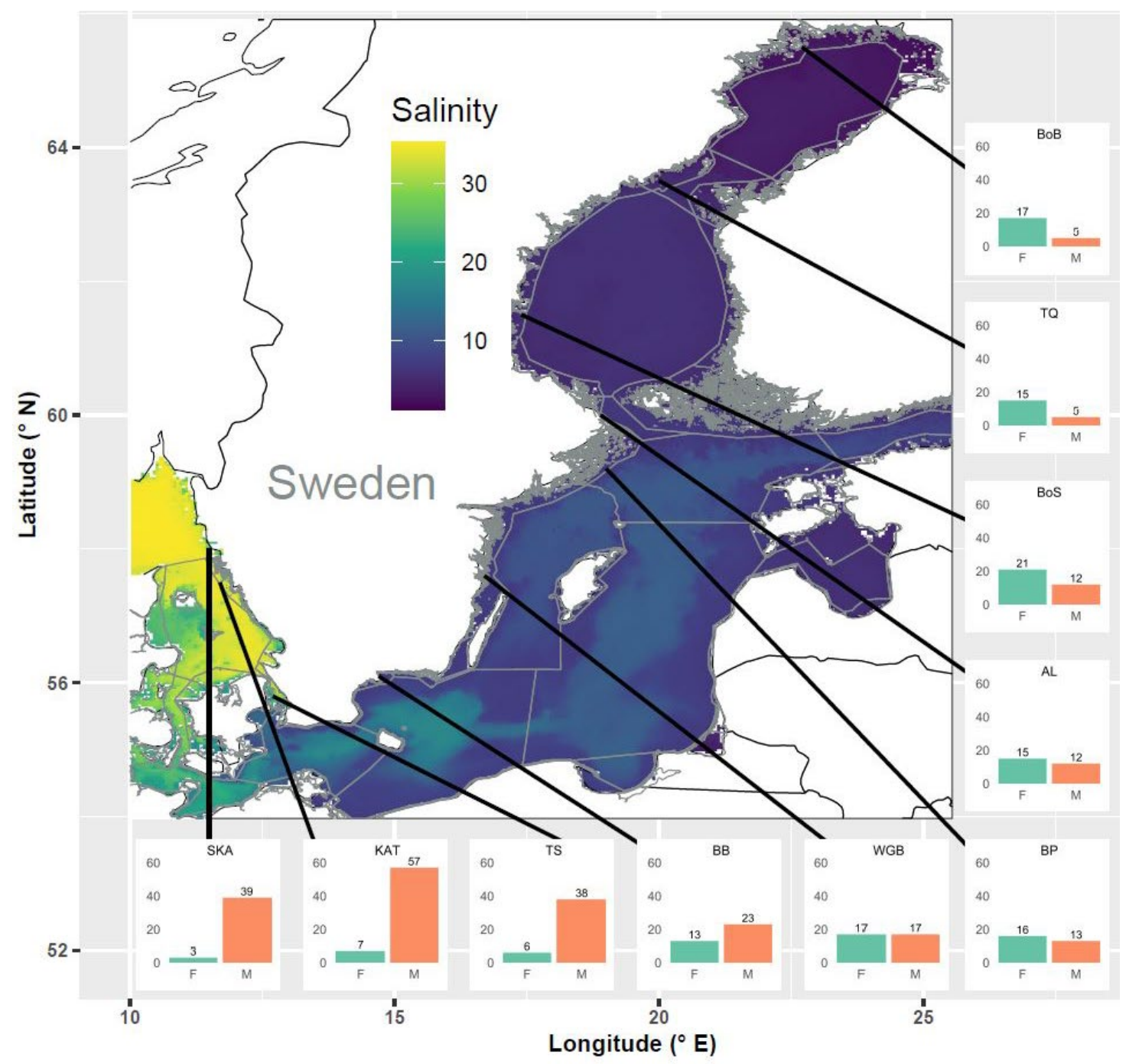

Figure 3. Map of the study area covering the Baltic Sea and the Skagerrak, color-coded by mean salinity. Bar plots show standardized fish species richness for each of the ten analyzed sub-basins, separately for species of freshwater (F) and marine (M) origin. SR was standardized across sub-basins to similar inventory completeness (Table S2: Black lines indicate the positions of the sub-basins, but the exact sampling sites were spread across the shallow areas of each of the sub-basins. 


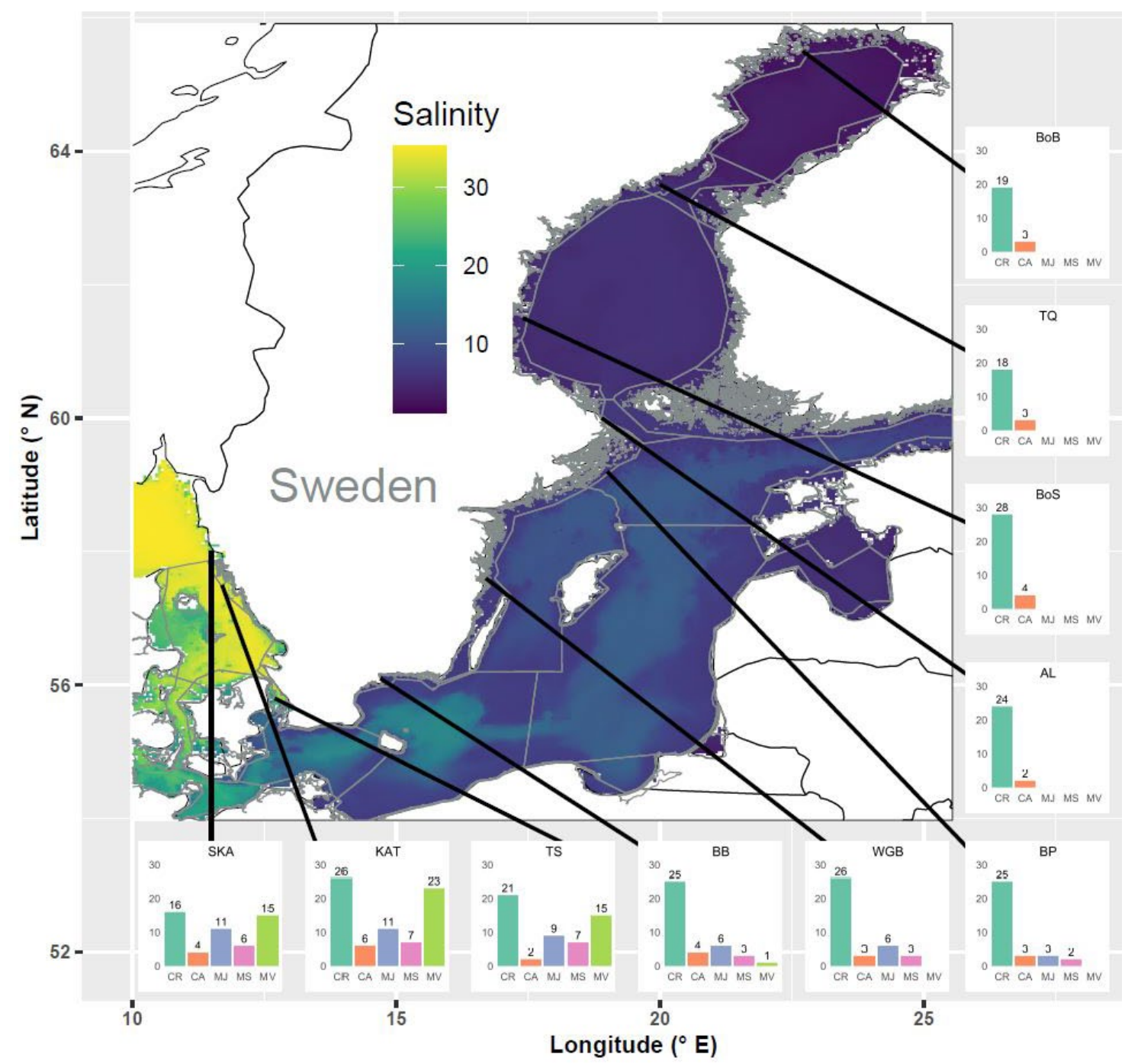

Figure 4. Map of the study area covering the Baltic Sea and the Skagerrak, color-coded by mean salinity. Bar plots show standardized fish species richness for each of the ten analyzed sub-basins, separately by habitat preference category, as CR: coastal resident, CA: catadromous or anadromous migrants, MJ: marine juvenile migrants, MS: marine seasonal migrants and MV: marine visitors. SR was standardized across sub-basins to similar inventory completeness (Table S2: Black lines indicate the positions of the sub-basins, but the exact sampling sites were spread across the shallow areas of each of the sub-basins. 


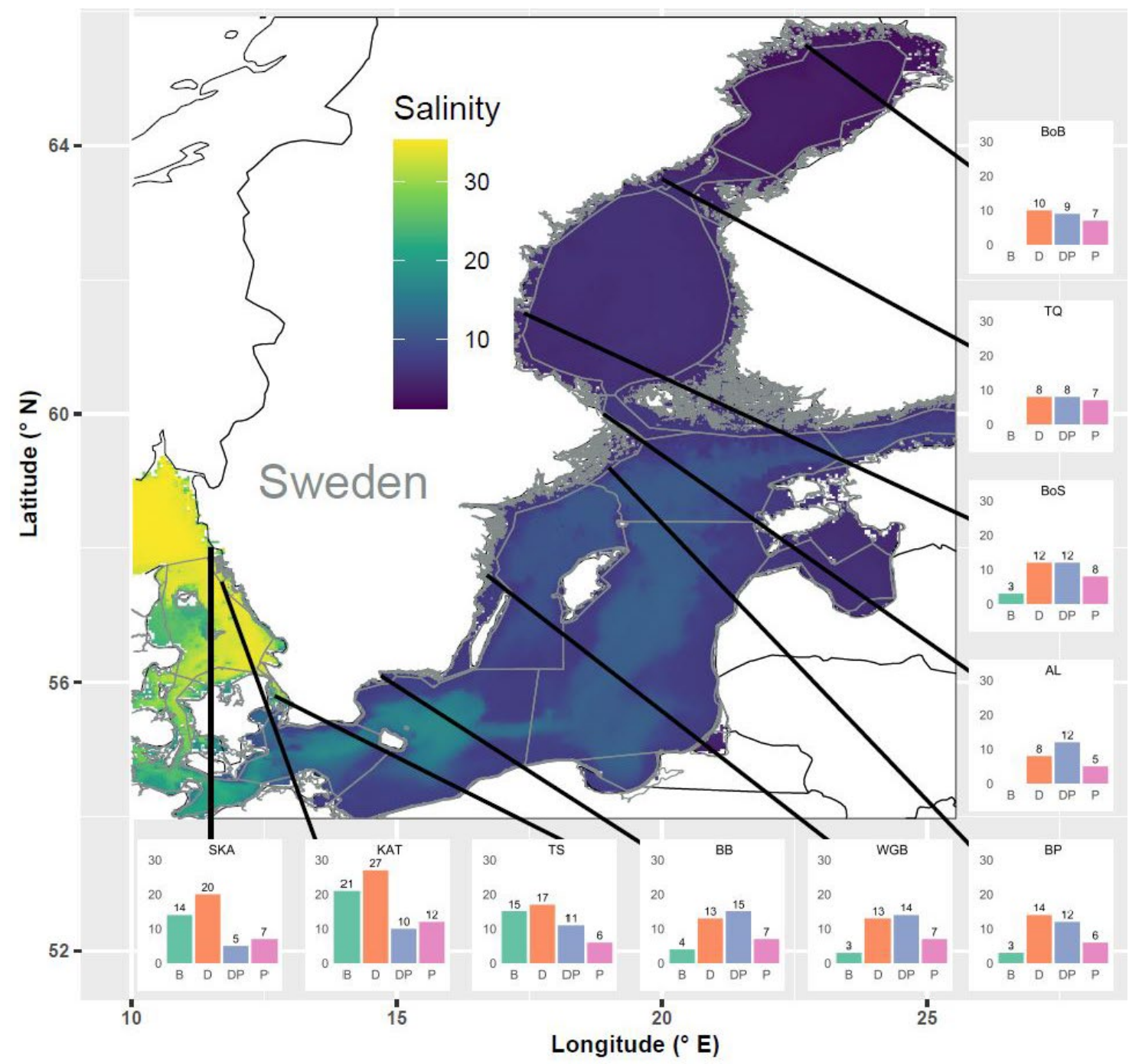

355 Figure 5. Map of the study area covering the Baltic Sea and the Skagerrak, color-coded by mean salinity. Bar plots show standardized fish species richness for each of the ten analyzed sub-basins, separately by vertical distribution category, with B: benthic, D: demersal, DP: demersal-pelagic and P: pelagic fish species. SR was standardized across sub-basins to similar inventory completeness (Table S2). Black lines indicate the positions of the sub-basins, but the exact sampling sites were spread across the shallow areas of each of the sub-basins. 


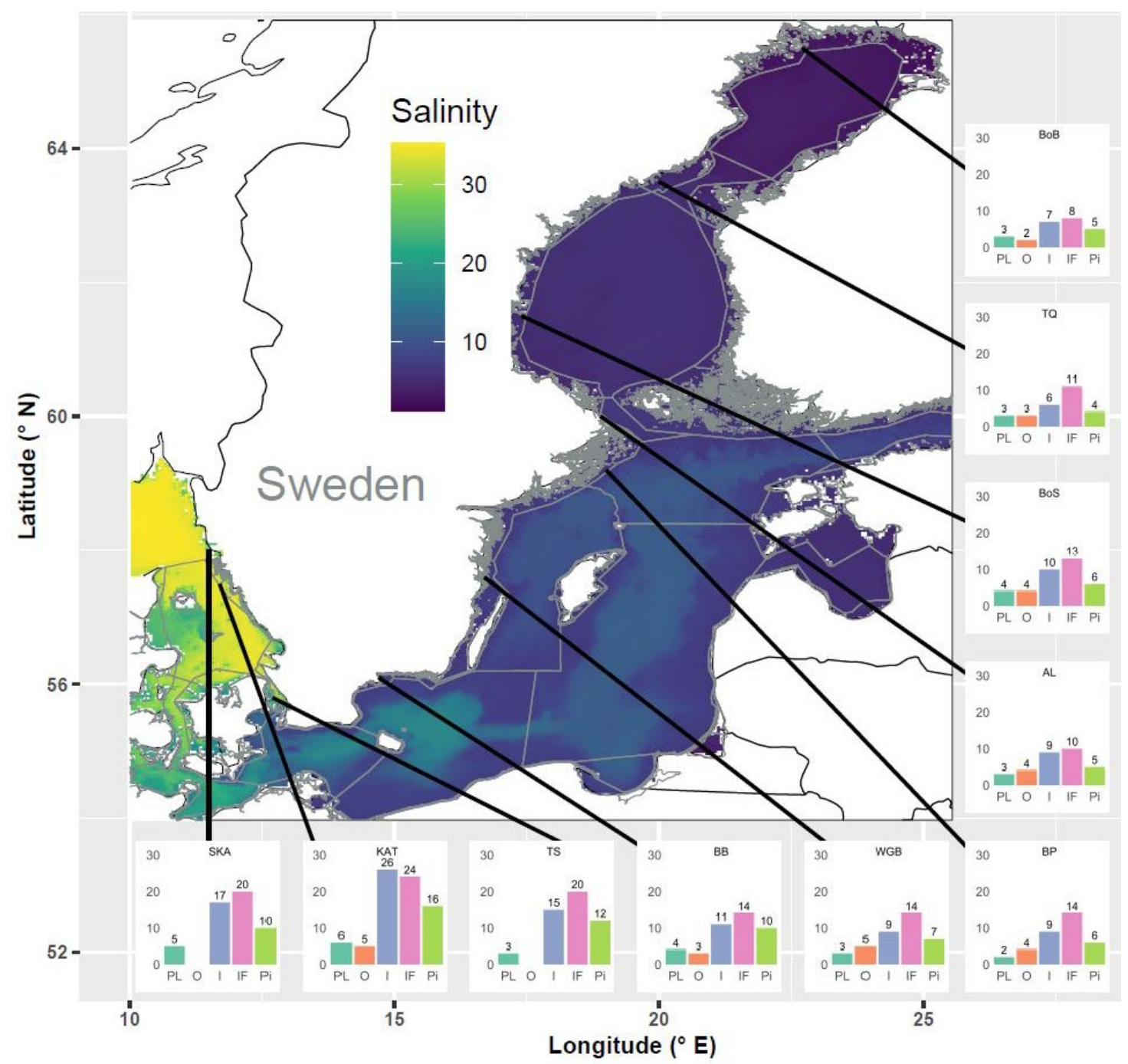

Figure 6. Map of the study area covering the Baltic Sea and the Skagerrak, color-coded by mean salinity. Bar plots show standardized fish species richness for each of the ten analyzed sub-basins, separately by feeding category, with trophic level increasing from left to right, and PL: planktivores, O: omnivores, I: invertebrate eaters, IF: invertebrate and fish eaters and Pi: piscivores. SR was standardized across sub-basins to similar inventory completeness (Table S2). Black lines indicate the positions of the sub-basins, but the exact sampling sites were spread across the shallow areas of each of the sub-basins.

\section{Discussion}

Data from species censuses have been called "probably the most basic data in ecology", as they are widely useful for example to define species ranges and biodiversity patterns, and support conservation efforts (Gaston \& Blackburn, 2000). A limitation for the use of taxonomic inventory data for biodiversity purposes, however, is their completeness, i.e. the fraction of species in a given location that has been sampled (Mora et al., 2008). In this study, the coastal fish taxonomic IC was found to be $\geq 98.5 \%$ for the 10 analyzed sub-basins. This is high compared to a 2008 assessment of marine fish species census data 
https://doi.org/10.5194/bg-2021-302

Preprint. Discussion started: 2 December 2021

(c) Author(s) 2021. CC BY 4.0 License.

\section{(c) $\underset{\mathrm{BY}}{\mathrm{BV}}$}

worldwide, where global IC averaged $79 \%$, indicating that ca. $21 \%$ of fish species still remained to be described. Marine fish IC exceeded $80 \%$ in less than $2 \%$ of marine areas worldwide, and the highest IC of $92 \%$ was found for reef-associated species (Mora et al., 2008). Similarly, a 2012 global assessment concluded that ca. 77\% of global marine fish SR were known to that date. Consequently, the rate of new fish species descriptions continues to be high, with e.g. 1,577 new marine fish species globally described during the years 1999-2008 (Appeltans et al., 2012). A comparison between the estimated SR per sub-basin (statistical extrapolation of the fish incidence data) and the corresponding compilation of total observed species richness, i.e. also including species presence information from additional data sources than systematic sampling, yielded a mean ratio of $1.07 \pm 0.03$ (Table 2). This suggests that the overall observed fish species lists for Swedish shallow coastal areas are close to complete for all analyzed sub-basins, and, in reverse, that the SR values estimated based on the fish incidence database ( $\left.\mathrm{SR}_{\mathrm{est}}\right)$ were realistic.

The SR of frequent and very frequent species (i.e. Shannon and Simpson diversity, ShD and SiD) were generally well described by the sample sizes available to date in the studied sub-basins, with calculated ShD and SiD being similar to both standardized and estimated values (where effects of differing sample sizes are considered; Table 3). This indicates that the remaining uncertainty in the fish $\mathrm{SR}_{\mathrm{obs}}$ is caused by a potential number of undetected rare species. This is a typical pattern, since wellknown species are usually common and have large geographical ranges, whereas newly discovered species are usually (more) locally rare and geographically concentrated (Appeltans et al., 2012; Mora et al., 2008; Pimm et al., 2014).

The most recent check-list of Baltic Sea macrospecies, i.e. containing fish species reported across Baltic countries at both shallow and deeper water depths but excluding the Skagerrak, currently contains 242 fish species (HELCOM, 2020). In our analyses of Swedish shallow coastal areas the total fish $\mathrm{SR}_{\mathrm{obs}}$ amounted to 144 (i.e., fish incidence data plus presence only data from additional data sources), also if Skagerrak is excluded. Comparing the sample-size corrected estimates of SR in coastal areas ( $\mathrm{SR}_{\text {est }}$ ) with HELCOM (2020) suggests that ca. 50-90\% of the so far reported Baltic Sea fish species are currently found in Swedish shallow coastal areas, depending on sub-basin (data from 1975-2020).

Our study reinforces that $\mathrm{SR}_{\mathrm{obs}}$ is strongly dependent on IC, and that comparing $\mathrm{SR}_{\mathrm{obs}}$ of species assemblages without accounting for this effect can lead to biased or even misleading conclusions (Chao \& Chiu, 2016; Chao \& Jost, 2015; Chao et al., 2020; Colwell \& Coddington, 1994; Colwell et al., 2012; Gotelli \& Colwell, 2001; Hill, 1973; Hsieh et al., 2016; Menegotto \& Rangel, 2018; Mora et al., 2008; Pimm et al., 2014). Instead, when sample sizes are not uniform among sites or over time, $\mathrm{SR}_{\mathrm{obs}}$ need to be corrected for IC before valid conclusions can be made. However, such methods have so far only rarely been used for coastal and estuarine fish assemblages (Waugh et al., 2019).

Besides the effects of sample size, SR and IC might in this study also have been differentially influenced by variation in fishing methods, as the predominating methods differed across sub-basins. Multi-mesh gill nets dominated in seven of the statistically analyzed sub-basins, while trap nets and trawls dominated in the other three (Table S1). One "sample" represents a different effort depending on the gear used and method, and each gear has a specific selectivity and efficiency, which strictly does not allow for direct comparison (Bergström et al., 2013; Waugh et al., 2019). For example, at the Swedish west coast, gill nets typically sample more species and individuals while fyke nets are more selective towards demersal and demersal-pelagic 
https://doi.org/10.5194/bg-2021-302

Preprint. Discussion started: 2 December 2021

(c) Author(s) 2021. CC BY 4.0 License.

\section{(c) $\underset{\mathrm{BY}}{\mathrm{BV}}$}

species (Bergström et al., 2013). Merging the multi-gear data into one analysis may have caused a certain bias in this regard. However, we argue that our approach was feasible given that the fishing methods used in the different sub-basins are optimized for the locally prevailing conditions, i.e. aiming to sample the existing assemblages as completely as possible (Bergström et al., 2013), as additional data from relevant trawl surveys were also included, and considering the long time horizon of data collection. Further supporting our approach, biodiversity metrics that were standardized against catch size revealed no consistent differences when comparing gill and fyke net samplings at the Swedish west coast (Bergström et al., 2013). Our assumption also appears justified given that $\mathrm{SR}_{\text {est }}$ was similar to $\mathrm{SR}_{\mathrm{obs}}$ including additional data sources (i.e. incidence data plus presence observations, Table 2), giving confidence that the potentially introduced bias due to differing fishing gear and methods did not strongly influence the general patterns and results of this comparative and large-scale statistical analysis.

415 As anticipated based on earlier Baltic Sea studies on fish (e.g. Hiddink \& Coleby, 2012; Ojaveer et al., 2010; Olsson et al., 2012) and other organism groups (e.g. Broman et al., 2019; Zettler et al., 2014), salinity was positively correlated with coastal fish SR (Table 4), with fish SR increasing ca. threefold across the ca. 10-fold salinity gradient (Table 2). That clear predominance of marine species in the most saline sub-basins compared to freshwater species in the inner parts of the Baltic Sea is in agreement with the fact that salinity functions as threshold or "ecological barrier" for the distribution of many freshwater and marine species (Olenin \& Leppäkoski, 1999; Vuorinen et al., 2015). It also corroborates patterns earlier reported for fish $\mathrm{SR}_{\mathrm{obs}}$ in three Baltic sub-basins (Hiddink \& Coleby, 2012) and estuaries in general (Whitfield, 2015). The relatively small number of freshwater fish species incidences observed in the higher salinity sub-basins in our study (Fig. 3) likely stems from sampling close to freshwater tributaries, and reflects that many freshwater fish species can withstand extended exposure to certain salinity levels (<ca. 9) and tolerate brief exposure to higher salinities (>ca. 15; Peterson \& Meador, 1994).

425 While temperature did not significantly correlate with observed $\mathrm{SR}, \mathrm{ShD}$ or $\mathrm{SiD}$, it was positively related with the standardized and estimated values (Table 4), which may indicate a temperature effect on fish biodiversity. Similarly, temperature has shown positive correlations with $\mathrm{SR}_{\mathrm{obs}}$ in North Atlantic demersal and benthopelagic fish assemblages (Gislason et al., 2020), and with fish $\mathrm{SR}_{\mathrm{obs}}$ in the coastal Norwegian Skagerrak (Lekve et al., 2002) as well as in estuaries worldwide (Vasconcelos et al., 2015), all being examples of the often found general pattern that broader-scale SR co-varies with climatic variables such as 430 temperature (Currie et al., 2004). However, given the clear relationship between salinity and the incidences of freshwater vs. marine fish species across the studied sub-basins (Fig. 3), we consider the studied salinity gradient to represent a case where the "physiological tolerance hypothesis" applies strongly, i.e. that SR in a particular area is limited by the number of species that can tolerate the local salinity conditions (Currie et al., 2004). In accordance, the regression models with salinity alone did not improve by adding temperature as additional explanatory variable. This conclusion is in agreement with observations from estuaries that fish SR is influenced by the broader distributions and habitat preference patterns of marine and freshwater species that can colonize these areas (Vasconcelos et al., 2015).

In compiling data from the last nearly five decades we assumed that salinity changes during this time period (1975-2020) have been minor compared to the pronounced spatial salinity gradient. According to monitoring data, changes in salinity have been noted between ca. +3 psu in the Kattegat and ca. -1 psu in the Bothnian Sea during 1980-2015 (Ammar et al., 2021), which 
https://doi.org/10.5194/bg-2021-302

Preprint. Discussion started: 2 December 2021

(c) Author(s) 2021. CC BY 4.0 License.

\section{(c) (i)}

440 can be considered small compared to the spatial salinity gradient ranging from 2 to 29 . Moreover, fish populations often show a lag of several years before biological changes following abiotic, environmental changes can be recorded (Daan et al., 2005). Considering temporal patterns in SR and community composition, it was earlier reported that the observed fish SR increased in Kattegat, Arkona Basin and the central Baltic during 2001-2008 (Hiddink \& Coleby, 2012), and that the observed SR of demersal fish increased in the Baltic Proper and the Bothnian Sea during ca. 1971-2013 (Törnroos et al., 2019). First-time

445 observations of known fish species in sub-basins where they were not previously caught have been related to increasing spring temperatures ( $+3-6{ }^{\circ} \mathrm{C}$ during 1980-2015; (Ammar et al., 2021). Such potential temporal patterns were not analyzed here, where we merged the fish incidence data across years to narrow down likely SR estimates for different sub-basins and focused on large-scale spatial patterns.

Concerning habitat preferences, a higher proportion of resident fish species was found in the less saline sub-basins. This agrees

450 with with the observed predominance of freshwater species in these areas, while clearly migrating species are often of marine origin (here classified as either marine juvenile migrants, marine seasonal migrants or marine visitors) and cannot tolerate low salinity. The pattern is also in line with life strategies of fishes in marine coastal areas and European estuaries generally, having an important role for ecological connectivity between open and coastal ecosystems (Franco et al., 2008). Concerning feeding habits, relatively more species were higher trophic-level feeders in the more saline sub-basins, while a more even distribution

455 of feeding groups emerged towards less saline areas (Fig. 6, Table 5). Comparative analyses between coastal and offshore areas could only be conducted for the Kattegatt, indicating a lower fish SR in the shallow offshore. This could be related to a higher habitat complexity and more variable substrates in the coastal area, supporting more species (Bonsdorff, 2006).

Benthic and demersal fish SR decreased with decreasing salinity, corroborating previous results where demersal fish $\mathrm{SR}_{\mathrm{obs}}$ decreased from the saline Kattegat to the less saline northern Baltic Proper (Pecuchet et al., 2016). This pattern further 460 corresponds with that the observed SR of benthic meio- and macrofauna, which are the dominating prey for benthic fish, also decreased with decreasing salinity in the Baltic Sea (Broman et al., 2019; Zettler et al., 2014). Taken together, and given that most Baltic Sea fish species feed on benthic invertebrates during at least part of their life cycle (Snickars et al., 2015), these patterns suggest that the strength of biological benthic-pelagic coupling through fish predation also likely differs along the Baltic Sea salinity gradient.

\section{Conclusions}

Since fish SR and a number of functional attributes changed along the salinity gradient, respective changes in the coastal fish communities may be foreseen if climate change further alters salinity conditions in the Baltic Sea. While the confidence in future salinity projections remains low (HELCOM, 2021), recent ensemble simulations estimate that the two main drivers of climate-related changes in salinity in the Baltic Sea region, increasing river runoff (leading to lower salinity) and sea level rise

470 (leading to higher salinity), approximately compensate each other, and may result in no net salinity changes (Meier et al., 2021). Mean (depth-integrated) observed Baltic Sea salinity did not change during 1982-2016, however, vertical changes were 
https://doi.org/10.5194/bg-2021-302

Preprint. Discussion started: 2 December 2021

(c) Author(s) 2021. CC BY 4.0 License.

(c) (i)

observed with freshening trends of the upper layer down to 40-50 $\mathrm{m}$ depth in most sub-basins, and increasing salinity below the halocline in the deep layer of some sub-basins (Liblik \& Lips, 2019). Hence, if not considering potential phenotypical acclimation or genetic adaptation, an upper layer freshening would, based on the results from this and earlier studies (e.g. Hiddink \& Coleby, 2012; MacKenzie et al., 2007; Pecuchet et al., 2016), likely lead to less species-rich native fish communities in shallow coastal areas, where more and more marine species are excluded. Further, successful recovery of marine overfished species may become less probable while certain freshwater fish species may be favored (MacKenzie et al., 2007; Peterson \& Meador, 1994). Indeed, marine fish species were negatively affected by a period of freshened conditions in the Baltic Sea during the ca. 1970-90s (Ojaveer \& Kalejs, 2005). Benthic fish species, being mostly of marine origin, may be especially vulnerable to freshening in the Baltic Sea region where their proportion in the fish assemblage is already relatively low to date. Besides salinity changes, fish SR and distribution may also be influenced by other climate-change related processes, including warming and resulting higher deep-water oxygen consumption rates, or changes in the Baltic Sea circulation (HELCOM, 2021; MacKenzie et al., 2007). Increasing water temperatures have already been linked to increased observed fish SR in the adjacent North Sea (Hiddink \& Ter Hofstede, 2008), and in the Kattegat (Hiddink \& Coleby, 2012). Further ecosystem-based assessments are needed to obtain realistic predictions of the net effect of such ongoing environmental changes on future fish $\mathrm{SR} /$ community composition and on how they may interact with human activities such as fishing patterns, and with conservation needs for biodiversity management.

\section{Code and data availability}

The data used in this study is publicly available via the SLU Database for Coastal Fish - KUL 490 (https://www.slu.se/en/departments/aquatic-resources1/databases/database-for-coastal-fish-kul/), the SLU Swedish Species Information Centre (https://www.artportalen.se/), the SMHI SHARKweb (https://www.smhi.se/en/services/opendata/national-archive-for-oceanographic-data), the FishBase (https://fishbase.se/search.php) and the E.U. Copernicus Marine Service Information (CMEMS, 2021). The SLU Trawl Survey data (Department of Aquatic Resources) and the R code used for analysis and plotting is available from B. Koehler upon request.

\section{Author contribution}

LB, MK and BK designed the study. LB, ME and MK compiled the data. MK and LB assigned the functional characteristics to the fish species. BK analyzed the data. BK and ME visualized the data. All co-authors discussed and validated the results. BK prepared the manuscript with contributions from all co-authors.

The authors declare that they have no conflict of interest. 
https://doi.org/10.5194/bg-2021-302

Preprint. Discussion started: 2 December 2021

(c) Author(s) 2021. CC BY 4.0 License.

(c) (i)

\section{Acknowledgements}

The study was enabled by the WATERS project (Waterbody Assessment Tools for Ecological Reference conditions and status in Sweden), funded by the Swedish Environmental Protection Agency and the Swedish Agency for Water and Marine management, and by the Department of Aquatic Resources, Swedish University of Agricultural Sciences. Dr. Malin Werner kindly contributed to the compilation of trawl data. The study is indebted to and was enabled by the Swedish national programs for fish, fisheries and marine environmental monitoring, hosted by SLU.

\section{References}

Ammar, Y., Niiranen, S., Otto, S. A., Möllmann, C., Finsinger, W., and Blenckner, T: The rise of novelty in marine ecosystems: The Baltic Sea case. Glob. Change Biol., 27(7), 1485-1499, https://doi.org/10.1111/gcb.15503, 2021.

510 Appeltans, W., Ahyong, S. T., Anderson, G., Angel, M. V., Artois, T., Bailly, N., Bamber, R., Barber, A., Bartsch, I., and Berta, A.: The magnitude of global marine species diversity. Curr. Biol., 22(23), 2189-2202, https://doi.org/10.1016/j.cub.2012.09.036, 2012.

Bergström, L., Karlsson, M., and Pihl, L.: Comparison of gill nets and fyke nets for the status assessment of coastal fish communities. WATERS Report, 2013:7, 2013.

515 Bonsdorff, E.: Zoobenthic diversity-gradients in the Baltic Sea: continuous post-glacial succession in a stressed ecosystem. J. Exp. Mar. Biol. Ecol., 330(1), 383-391, https://doi.org/10.1016/j.jembe.2005.12.041, 2006.

Broman, E., Raymond, C., Sommer, C., Gunnarsson, J. S., Creer, S., and Nascimento, F. J.: Salinity drives meiofaunal community structure dynamics across the Baltic ecosystem. Mol. Ecol., 28(16), 3813-3829, https://doi.org/10.1111/mec.15179, 2019.

520 Byrnes, J. E., Gamfeldt, L., Isbell, F., Lefcheck, J. S., Griffin, J. N., Hector, A., Cardinale, B. J., Hooper, D. U., Dee, L. E., and Emmett Duffy, J.: Investigating the relationship between biodiversity and ecosystem multifunctionality: challenges and solutions. Methods Ecol. Evol., 5(2), 111-124, https://doi.org/10.1111/2041-210X.12143, 2014.

Chao, A., and Jost, L.: Coverage-based rarefaction and extrapolation: standardizing samples by completeness rather than size. Ecology, 93(12), 2533-2547, https://doi.org/10.1890/11-1952.1, 2012.

525 Chao, A., and Jost, L.: Estimating diversity and entropy profiles via discovery rates of new species. Methods Ecol. Evol., 6(8), 873-882, https://doi.org/10.1111/2041-210X.12349, 2015.

Chao, A., and Chiu, C. H.: Nonparametric estimation and comparison of species richness. In: eLS. John Wiley and Sons, Ltd: Chichester. https://doi.org/10.1002/9780470015902.a0026329, 2016.

Chao, A., Gotelli, N. J., Hsieh, T., Sander, E. L., Ma, K., Colwell, R. K., and Ellison, A. M.: Rarefaction and extrapolation 530 with Hill numbers: a framework for sampling and estimation in species diversity studies. Ecol. Monogr., 84(1), 45-67, https://doi.org/10.1890/13-0133.1, 2014. 
https://doi.org/10.5194/bg-2021-302

Preprint. Discussion started: 2 December 2021

(c) Author(s) 2021. CC BY 4.0 License.

\section{(c) (i)}

Chao, A., Kubota, Y., Zelený, D., Chiu, C. H., Li, C. F., Kusumoto, B., Yasuhara, M., Thorn, S., Wei, C. L., and Costello, M. J.: Quantifying sample completeness and comparing diversities among assemblages. Ecol. Res., 35(2), 292-314, https://doi.org/10.1111/1440-1703.12102, 2020.

535 CMEMS: EU Copernicus Marine Service Information, https://resources.marine.copernicus.eu/productdetail/BALTICSEA_REANALYSIS_PHY_003_011/INFORMATION, last access: 10 November 2021.

Colwell, R., and Coddington, J.: Estimating terrestrial biodiversity through extrapolation. Philos. T. R. Soc. B, 345, 101-118, https://doi.org/10.1098/rstb.1994.0091, 1994.

Colwell, R. K., Chao, A., Gotelli, N. J., Lin, S.-Y., Mao, C. X., Chazdon, R. L., and Longino, J. T.: Models and estimators

540 linking individual-based and sample-based rarefaction, extrapolation and comparison of assemblages. J. Plant Ecol., 5 (1), 321, https://doi.org/10.1093/jpe/rtr044, 2012.

Currie, D. J., Mittelbach, G. G., Cornell, H. V., Field, R., Guégan, J. F., Hawkins, B. A., Kaufman, D. M., Kerr, J. T., Oberdorff, T., and O'Brien, E.: Predictions and tests of climate-based hypotheses of broad-scale variation in taxonomic richness. Ecol. Lett., 7(12), 1121-1134, https://doi.org/10.1111/j.1461-0248.2004.00671.x, 2004.

545 Daan, N., Gislason, H., G. Pope, J., and C. Rice, J.: Changes in the North Sea fish community: evidence of indirect effects of fishing? ICES J. Mar. Sci., 62(2), 177-188, https://doi.org/10.1016/j.icesjms.2004.08.020, 2005.

Duffy, J. E., Godwin, C. M., and Cardinale, B. J.: Biodiversity effects in the wild are common and as strong as key drivers of productivity. Nature, 549(7671), 261-264, https://doi.org/10.1038/nature238862017, 2017.

Duncan, C., Thompson, J. R., and Pettorelli, N.: The quest for a mechanistic understanding of biodiversity-ecosystem services relationships. P. Roy. Soc. B-Biol. Sci., 282(1817), https://doi.org/10.1098/rspb.2015.1348, 2015.

Durack, P. J., Wijffels, S. E., and Matear, R. J.: Ocean salinities reveal strong global water cycle intensification during 1950 to 2000. Science, 336(6080), 455-458, https://doi.org/10.1126/science.1212222, 2012.

Elliott, M., and Dewailly, F.: The structure and components of European estuarine fish assemblages. Neth. J. Aquat. Ecol., 29(3), 397-417, https://doi.org/10.1007/BF02084239, 1995.

555 Franco, A., Elliott, M., Franzoi, P., and Torricelli, P.: Life strategies of fishes in European estuaries: the functional guild approach. Mar. Ecol. Prog. Ser., 354, 219-228, https://doi.org/10.3354/meps07203, 2008.

Froese, R., and Pauly, D. (Eds.): FishBase. World Wide Web electronic publication. www.fishbase.org, version 06/2021, 2021. Gaston, K., and Blackburn, T. (Eds.): Pattern and Process in Macroecology. Blackwell Science Ltd, Oxford, England, https://doi.org/10.1002/9780470999592, 2000.

560 Gislason, H., Collie, J., MacKenzie, B. R., Nielsen, A., Borges, M. d. F., Bottari, T., Chaves, C., Dolgov, A. V., Dulčić, J., and Duplisea, D.: Species richness in North Atlantic fish: Process concealed by pattern. Global Ecol. Biogeogr., 29(5), 842-856, https://doi.org/10.1111/geb.13068, 2020.

Gotelli, N. J., and Colwell, R. K.: Quantifying biodiversity: procedures and pitfalls in the measurement and comparison of species richness. Ecol. Lett., 4(4), 379-391, https://doi.org/10.1046/j.1461-0248.2001.00230.x, 2001. 
https://doi.org/10.5194/bg-2021-302

Preprint. Discussion started: 2 December 2021

(c) Author(s) 2021. CC BY 4.0 License.

(c) (i)

565 Griffiths, J. R., Kadin, M., Nascimento, F. J., Tamelander, T., Törnroos, A., Bonaglia, S., Bonsdorff, E., Brüchert, V., Gårdmark, A., and Järnström, M.: The importance of benthic-pelagic coupling for marine ecosystem functioning in a changing world. Glob. Change Biol., 23(6), 2179-2196, https://doi.org/10.1111/gcb.13642, 2017.

HELCOM: State of the Baltic Sea - Second HELCOM holistic assessment 2011-2016. Baltic Sea Environment Proceedings, $155,2018$.

570 HELCOM: HELCOM Checklist 2.0 of Baltic Sea Macrospecies. Baltic Sea Environment Proceedings, 174, 2020.

HELCOM: Climate Change in the Baltic Sea. 2021 Fact Sheet. Baltic Sea Environment Proceedings, 180, 2021.

Herlemann, D. P., Lundin, D., Andersson, A. F., Labrenz, M., and Jürgens, K.: Phylogenetic signals of salinity and season in bacterial community composition across the salinity gradient of the Baltic Sea. Front. Microbiol., 7, Article 1883. https://doi.org/10.3389/fmicb.2016.01883, 2016.

575 Hiddink, J., and Ter Hofstede, R.: Climate induced increases in species richness of marine fishes. Glob. Change Biol., 14(3), 453-460, https://doi.org/10.1111/j.1365-2486.2007.01518.x, 2008.

Hiddink, J. G., and Coleby, C.: What is the effect of climate change on marine fish biodiversity in an area of low connectivity, the Baltic Sea? Global Ecol. Biogeogr., 21(6), 637-646, https://doi.org/10.1111/j.1466-8238.2011.00696.x, 2012.

Hill, M. O.: Diversity and evenness: a unifying notation and its consequences. Ecology, 54(2), 427-432, 580 https://doi.org/10.2307/1934352, 1973.

Hsieh, T., Ma, K., and Chao, A.: iNEXT: an R package for rarefaction and extrapolation of species diversity (Hill numbers): Methods Ecol. Evol., 7(12), 1451-1456, https://doi.org/10.1111/2041-210X.12613, 2016.

Hu, Y. O., Karlson, B., Charvet, S., and Andersson, A. F.: Diversity of pico-to mesoplankton along the $2000 \mathrm{~km}$ salinity gradient of the Baltic Sea. Front. Microbiol., 7, Article 679. https://doi.org/10.3389/fmicb.2016.00679, 2016.

585 IPBES: Global assessment report on biodiversity and ecosystem services of the Intergovernmental Science-Policy Platform on Biodiversity and Ecosystem Services, edited by: Brondizio, E. S., Settele, J., Díaz, S. and Ngo, H. T.. IPBES secretariat, Bonn, Germany. 1148 pp. https://doi.org/10.5281/zenodo.3831673, 2019.

Johannesson, K., and Andre, C.: Invited review: Life on the margin: genetic isolation and diversity loss in a peripheral marine ecosystem, the Baltic Sea. Mol. Ecol., 15(8), 2013-2029, https://doi.org/10.1111/j.1365-294X.2006.02919.x, 2006.

590 Kaskela, A., Kotilainen, A., Al-Hamdani, Z., Leth, J., and Reker, J.: Seabed geomorphic features in a glaciated shelf of the Baltic Sea. Estuar. Coast. Shelf S., 100, 150-161, https://doi.org/10.1016/j.ecss.2012.01.008, 2012.

Klier, J., Dellwig, O., Leipe, T., Jürgens, K., and Herlemann, D. P.: Benthic bacterial community composition in the oligohaline-marine transition of surface sediments in the Baltic Sea based on rRNA analysis. Front. Microbiol., 9, 236, https://doi.org/10.3389/fmicb.2018.00236, 2018.

595 Koli, L.: Suomen Kalat, edited by: Porvoo, W., 1990 (in Finish).

Kraufvelin, P., Pekcan-Hekim, Z., Bergström, U., Florin, A.-B., Lehikoinen, A., Mattila, J., Arula, T., Briekmane, L., Brown, E. J., and Celmer, Z.: Essential coastal habitats for fish in the Baltic Sea. Estuar. Coast. Shelf S., 204, 14-30, https://doi.org/10.1016/j.ecss.2018.02.014, 2018. 
https://doi.org/10.5194/bg-2021-302

Preprint. Discussion started: 2 December 2021

(c) Author(s) 2021. CC BY 4.0 License.

Kullander, S. O.: Förteckning över svenska fiskar, https://www.yumpu.com/es/document/read/19727234/forteckning-over-

svenska-fiskar-pdf-naturhistoriska-riksmuseet, last access: 10 November 2002. In Swedish.

Laikre, L., Palm, S., and Ryman, N.: Genetic population structure of fishes: implications for coastal zone management. Ambio, 34(2), 111-119, https://doi.org/10.1579/0044-7447-34.2.111, 2005.

Lappalainen, A., Shurukhin, A., Alekseev, G., and Rinne, J.: Coastal-Fish Communities along the Northern Coast of the Gulf of Finland, Baltic Sea: Responses to Salinity and Eutrophication. Int. Rev. Hydrobiol., 85(5-6), 687-696, https://doi.org/10.1002/1522-2632(200011)85:5/6<687::AID-IROH687>3.0.CO;2-4, 2000.

Lekve, K., Stenseth, N. C., Gjøsæter, J., and Dolédec, S.: Species richness and environmental conditions of fish along the Norwegian Skagerrak coast. ICES J. Mar. Sci., 59(4), 757-769, https://doi.org/10.1006/jmsc.2002.1247, 2002.

Liblik, T., and Lips, U.: Stratification has strengthened in the Baltic Sea-an analysis of 35 years of observational data. Front. Earth Sci., 7, 174, https://doi.org/10.3389/feart.2019.00174, 2019.

MacKenzie, B. R., Gislason, H., Möllmann, C., and Köster, F. W.: Impact of 21 st century climate change on the Baltic Sea fish community and fisheries. Glob. Change Biol., 13(7), 1348-1367, https://doi.org/10.1111/j.1365-2486.2007.01369.x, 2007. Meier, H. E. M., Kniebusch, M., Dieterich, C., Gröger, M., Zorita, E., Elmgren, R., Myrberg, K., Ahola, M., Bartosova, A., Bonsdorff, E., Börgel, F., Capell, R., Carlén, I., Carlund, T., Carstensen, J., Christensen, O. B., Dierschke, V., Frauen, C., Frederiksen, M., Gaget, E., Galatius, A., Haapala, J. J., Halkka, A., Hugelius, G., Hünicke, B., Jaagus, J., Jüssi, M., Käyhkö, 615 J., Kirchner, N., Kjellström, E., Kulinski, K., Lehmann, A., Lindström, G., May, W., Miller, P., Mohrholz, V., Müller-Karulis, B., Pavón-Jordán, D., Quante, M., Reckermann, M., Rutgersson, A., Savchuk, O. P., Stendel, M., Tuomi, L., Viitasalo, M., Weisse, R., and Zhang, W.: Climate Change in the Baltic Sea Region: A Summary. Earth Sys. Dynam. Disc. [preprint]. https://doi.org/10.5194/esd-2021-67, in review, 2021.

Menegotto, A., and Rangel, T. F.: Mapping knowledge gaps in marine diversity reveals a latitudinal gradient of missing species richness. Nat. Commun., 9(1), 1-6, https://doi.org/10.1038/s41467-018-07217-7, 2018.

Middelboe, A. L., Sand-Jensen, K., and Brodersen, K.: Patterns of macroalgal distribution in the Kattegat-Baltic region. Phycologia, 36(3), 208-219, https://doi.org/10.2216/i0031-8884-36-3-208.1, 1997.

Momigliano, P., Denys, G. P., Jokinen, H., and Merilä, J.: Platichthys solemdali sp. nov. (Actinopterygii, Pleuronectiformes): a new flounder species from the Baltic Sea. Front. Mar. Sci., 5, Article 225. https://doi.org/10.3389/fmars.2018.00225, 2018.

625 Mora, C., Tittensor, D. P., and Myers, R. A.: The completeness of taxonomic inventories for describing the global diversity and distribution of marine fishes. P. Roy. Soc. B-Biol. Sci., 275(1631), 149-155, https://doi.org/10.1098/rspb.2007.1315, 2008. O'Gorman, E. J., Yearsley, J. M., Crowe, T. P., Emmerson, M. C., Jacob, U., and Petchey, O. L.: Loss of functionally unique species may gradually undermine ecosystems. P. Roy. Soc. B-Biol. Sci., 278(1713), 1886-1893, https://doi.org/10.1098/rspb.2010.2036, 2011.

630 Ojaveer, E., and Kalejs, M.: The impact of climate change on the adaptation of marine fish in the Baltic Sea. ICES J. Mar. Sci., 62(7), 1492-1500, https://doi.org/10.1016/j.icesjms.2005.08.002, 2005. 
https://doi.org/10.5194/bg-2021-302

Preprint. Discussion started: 2 December 2021

(c) Author(s) 2021. CC BY 4.0 License.

\section{(c) (1)}

Ojaveer, H., Jaanus, A., MacKenzie, B. R., Martin, G., Olenin, S., Radziejewska, T., Telesh, I., Zettler, M. L., and Zaiko, A.: Status of biodiversity in the Baltic Sea. PloS ONE, 5(9), e12467. https://doi.org/10.1371/journal.pone.0012467, 2010.

Olenin, S., and Leppäkoski, E.: Non-native animals in the Baltic Sea: alteration of benthic habitats in coastal inlets and lagoons. 635 Hydrobiologia, 393, 233-243, https://doi.org/10.1023/A:1003511003766, 1999.

Olli, K., Ptacnik, R., Klais, R., and Tamminen, T.: Phytoplankton species richness along coastal and estuarine salinity continua. Am. Nat., 194(2), E41-E51, https://orcid.org/0000-0003-2895-1273, 2019.

Olsson, J., Bergström, L., and Gårdmark, A.: Abiotic drivers of coastal fish community change during four decades in the Baltic Sea. ICES J. Mar. Sci., 69(6), 961-970, https://doi.org/10.1093/icesjms/fss072, 2012.

640 Pan, J., Marcoval, M. A., Bazzini, S. M., Vallina, M. V., and Marco, S.: Coastal marine biodiversity: Challenges and threats, in: Marine Ecology in a Changing World, edited by: Arias, A. H. and Menendez, M. C., CRC Press, Boca Raton, United States, 43-67, https://doi.org/10.1201/b16334-3, 2013.

Pecuchet, L., Törnroos, A., and Lindegren, M.: Patterns and drivers of fish community assembly in a large marine ecosystem. Mar. Ecol. Prog. Ser., 546, 239-248, https://doi.org/10.3354/meps11613, 2016.

645 Pekcan-Hekim, Z., Gårdmark, A., Karlson, A. M., Kauppila, P., Bergenius, M., and Bergström, L.: The role of climate and fisheries on the temporal changes in the Bothnian Bay foodweb. ICES J. Mar. Sci., 73(7), 1739-1749, https://doi.org/10.1093/icesjms/fsw032, 2016.

Peterson, M. S., and Meador, M. R.: Effects of salinity on freshwater fishes in coastal plain drainages in the southeastern US. Rev. Fish. Sci., 2(2), 95-121, https://doi.org/10.1080/10641269409388554, 1994.

Pihl, L., and Wennhage, H.: Structure and diversity of fish assemblages on rocky and soft bottom shores on the Swedish west coast. J. Fish Biol., 61, 148-166, https://doi.org/10.1111/j.1095-8649.2002.tb01768.x, 2002.

Pihl, L., Wennhage, H., and Nilsson, S.: Fish assemblage structure in relation to macrophytes and filamentous epiphytes in shallow non-tidal rocky-and soft-bottom habitats. Environ. Biol. Fish., 39(3), 271-288, https://doi.org/10.1007/BF00005129, 1994.

655 Pimm, S. L., Jenkins, C. N., Abell, R., Brooks, T. M., Gittleman, J. L., Joppa, L. N., Raven, P. H., Roberts, C. M., and Sexton, J. O.: The biodiversity of species and their rates of extinction, distribution, and protection. Science, 344(6187): https://doi.org/10.1126/science.1246752, 2014.

R Core Team: R: A language and environment for statistical computing. Version 4.0.4. R Foundation for Statistical Computing, Vienna, Austria. URL https://www.R-project.org/. 2021.

660 Reiss, J., Bridle, J. R., Montoya, J. M., and Woodward, G.: Emerging horizons in biodiversity and ecosystem functioning research. Trends Ecol. Evol., 24(9), 505-514, https://doi.org/10.1016/j.tree.2009.03.018, 2009.

Rooney, N., and McCann, K. S.: Integrating food web diversity, structure and stability. Trends Ecol. Evol., 27(1), 40-46, 2012. Russell, G.: Recent evolutionary changes in the algae of the Baltic Sea. Brit. Phycol. J., 20(2), 87-104, https://doi.org/10.1080/00071618500650111, 1985. 
https://doi.org/10.5194/bg-2021-302

Preprint. Discussion started: 2 December 2021

(c) Author(s) 2021. CC BY 4.0 License.

(c) (i)

665 Snickars, M., Weigel, B., and Bonsdorff, E.: Impact of eutrophication and climate change on fish and zoobenthos in coastal waters of the Baltic Sea. Mar. Biol., 162(1), 141-151, https://doi.org/10.1007/s00227-014-2579-3, 2015.

Thorman, S.: Seasonal colonisation and effects of salinity and temperature on species richness and abundance of fish of some brackish and estuarine shallow waters in Sweden. Ecography, 9(2), 126-132, https://doi.org/10.1111/j.16000587.1986.tb01201.x, 1986.

670 Törnroos, A., Pecuchet, L., Olsson, J., Gårdmark, A., Blomqvist, M., Lindegren, M., and Bonsdorff, E.: Four decades of functional community change reveals gradual trends and low interlinkage across trophic groups in a large marine ecosystem. Glob. Change Biol., 25(4), 1235-1246, https://doi.org/10.1111/gcb.14552, 2019.

Vasconcelos, R. P., Henriques, S., França, S., Pasquaud, S., Cardoso, I., Laborde, M., and Cabral, H. N.: Global patterns and predictors of fish species richness in estuaries. J. Anim. Ecol., 84(5), 1331-1341, https://doi.org/10.1111/1365-2656.12372, 6752015.

Vuorinen, I., Hänninen, J., Rajasilta, M., Laine, P., Eklund, J., Montesino-Pouzols, F., Corona, F., Junker, K., Meier, H. M., and Dippner, J. W.: Scenario simulations of future salinity and ecological consequences in the Baltic Sea and adjacent North Sea areas-implications for environmental monitoring. Ecol. Indic., 50, 196-205, https://doi.org/10.1016/j.ecolind.2014.10.019, 2015.

680 Waugh, A., Elliott, M., and Franco, A.: Debunking paradigms in estuarine fish species richness. Mar. Ecol. Prog. Ser., 613, 125-138, https://doi.org/10.3354/meps12883, 2019.

Whitfield, A.: Why are there so few freshwater fish species in most estuaries? J. Fish Biol., 86(4), 1227-1250, https://doi.org/10.1111/jfb.12641, 2015.

Wikström A., M. M.: Provfiske med nordiska kustöversiktsgarn utmed två kustområden I Hanöbukten: Pukavik/Elleholm och

685 Skräbeåns mynning/Valjeviken. 2009. In Swedish.

Yeo, I. K., and Johnson, R. A.: A new family of power transformations to improve normality or symmetry. Biometrika, 87(4), 954-959, https://doi.org/10.1093/biomet/87.4.954, 2000.

Zettler, M. L., Karlsson, A., Kontula, T., Gruszka, P., Laine, A. O., Herkül, K., Schiele, K. S., Maximov, A., and Haldin, J.: Biodiversity gradient in the Baltic Sea: a comprehensive inventory of macrozoobenthos data. Helgoland Mar. Res., 68(1), 49-

690 57, https://doi.org/10.1007/s10152-013-0368-x, 2014. 